Pace University

DigitalCommons@Pace

$1-1-1990$

\title{
Regulating Regulators: The Legal Environment of the State
}

David S. Cohen

Pace Law School

Follow this and additional works at: https://digitalcommons.pace.edu/lawfaculty

Part of the Law and Economics Commons, Law and Society Commons, and the Public Law and Legal Theory Commons

\section{Recommended Citation}

David S. Cohen, Regulating Regulators: The Legal Environment of the State, U. Toronto L.J. 213 (1990), http://digitalcommons.pace.edu/lawfaculty/423/.

This Article is brought to you for free and open access by the School of Law at DigitalCommons@Pace. It has been accepted for inclusion in Pace Law Faculty Publications by an authorized administrator of DigitalCommons@Pace. For more information, please contact dheller2@law.pace.edu. 
One purpose of law is to reduce the costs of accidents through their reallocation by the state. ${ }^{1}$ In this paper I analyse a particular and problematical application of that idea - the impact of tort on accidents ${ }^{2}$

* Faculty of Law, University of British Columbia

$\dagger$ This paper was written with the assistance of a research grant from the Social Sciences and Humanities Research Council of Canada. Much of this paper was written while I was a visiting professor at the Faculty of Law of the University of Toronto in conjunction with the Connaught Program in Legal Theory. I have benefited from discussions at the Law and Economic Workshop at the University of Toronto and from comments by Professor Michael Trebilcock. I thank my research assistant, James Penner who contributed much to this paper. In particular, the descriptions of current bureaucratic practices and the treatment of damage claims against the federal government would not have been possible without his perseverance and conscientiousness.

1 To be precise, one function of tort law is to reduce the risk of accident losses. To a large extent my analysis will adopt an ex ante perspective on law. That is, I will analyse and evaluate legal rules and processes in the light of their influence on the accidentavoidance behaviour of governments and bureaucrats that will take place after the rule has been articulated.

2 The term 'accidents' is intended to exclude from analysis losses that are the product of deliberate distributive judgments by representative institutions. I will assume for the purposes of this paper that if legislative bodies redistribute wealth, it is inappropriate for judicial institutions to interfere with that decision. Thus, tort liability as I conceive it is trumped by a demonstration that the loss was actually a disguised form of taxation. See J. Quinn and M.J. Trebilcock 'Compensation, Transition Costs, and Regulatory Change' (1982) 32 UTLJ 117 , at 173. As Richard Epstein has said, there is 'a circular and self-defeating quality upon insistence upon explicit compensation': 'Taxation, Regulation and Confiscation' (1982) 20 Osgoode Hall LJ 433, at 436.

The difficulty, of course, is to distinguish between inadvertent accidents and taxation decisions. One also has to determine how to respond when the government decises ex post to characterize an inadvertent accident as a taxation decision - that is, should what was an accident then be recognized as a non-accident? Perhaps one technique to achieve the first objective is to presume that losses are inadvertent unless the state demonstrates and acknowledges that it was engaged in wealth redistribution. One advantage of this technique is that costs associated with discovery against the state would be borne by the state rather than by victims. It is probably true that if costs were allocated in this fashion they would be lower than if they were allocated to random members of the public who happened to be victimized by state action. This presumption appears to be operating in current judicial decisions. See City of Kamloops v. Nielsen [1984] 2 SCR 1, 10 DLR (4th) 641; Dorschell v. City of Cambridge (1980) 117 DLR (3d) 630 (Ont. CA).

My analysis will exclude an examination of contract claims against the state. The contract liability of the state involves questions of bureaucratic financial accountability, and must take into account the ability of the parties to allocate risks ex ante. Assuming that the parties have negotiated a contract, it is possible to argue that liability rules should reflect the private arrangements the parties reached or ought to have reached. See R. Coase 'The Problem of Social Cost' (1960) 3 J. of Law E' Econ. 1.

(1990), 40 UNIVERSITY OF TORONTO LAW JOURNAL 213 
generated by the activities of the state itself through public bureaucrats and public bureaucracies. ${ }^{3} \mathrm{My}$ object is to evaluate the role of liability rules in reducing primary accident costs, ${ }^{4}$ and in particular to examine the incentive effects of liability rules on the behaviour of the state as an institution as well as on individual state actors. ${ }^{5}$

It is true that allocative efficiency may suggest the establishment of loss-shifting mechanisms even if primary accident costs are unaffected by liability rules. For example, it may be possible to justify compensation if a shifting of losses from the individual to the community reduces the effect of accidents that do occur, and it may be that the distributive consequences of loss-shifting will increase aggregate social welfare. Yet in these cases $I$ am not justifying compensation on the ground that bureaucrats will act differently in the future -with associated benefits related to a reduction in the number and magnitude of accidents. Rather, I am arguing for compensation on the ground that loss-spreading is allocatively efficient in its own right. ${ }^{6}$

In this paper I focus on the first issue - that is, the ability of tort law to reduce primary costs, or losses associated with the number and seriousness of accidents. ${ }^{7}$ In one sense I will be analysing the state as if it were a private

3 I should point out that this paper envisages the state as an institution that engages in activities with allocative implications and is motivated to allocate its own resources efficiently. There are no doubt innumerable other equally (and perhaps more) virtuous social objectives in addition to efficiency. This focus on the state and efficiency does not mean that efficiency is the only or the most important normative idea in government. It is one; and it is one that is susceptible to an analysis that focuses on the incentive effect of economic signals generated by compensation awards.

4 'Primary costs' refers to the subset of the losses associated with accidents which are a product of the magnitude and severity of the losses and the probability of the occurrence of the event that generates the loss. It is distinguishable from secondary costs, which relate to the distribution of losses across members of society, and tertiary costs, which relate to the administrative costs of loss-shifting institutions and instruments.

5 Two earlier efforts using economic analysis to investigate government liability are $\mathrm{M}$. Spitzer 'An Economic Analysis of Sovereign Immunity in Tort' (1977) $5^{\circ}$ So. Cal. LR $5^{15}$, and F. James 'Tort Liability of Governmental Units and Their Officers' (1955) 22 U. Chi. LR 610 .

I will assume for the purposes of this paper that victim behaviour is independent of the particular liability rules applied to the state. There is no doubt that if that assumption is relaxed, optimal rules evaluated in terms of their ability to reduce primary accident costs will be substantially different from the proposals offered here. See L. Kaplow 'An Economic Analysis of Transition Rules' (1986) 99 Harv. LR ${ }_{5} 11$.

6 Guido Calabresi refers to this phenomenon as 'secondary cost avoidance.' See G. Calabresi The Costs of Accidents (New Haven: Yale University Press 1970). The benefits associated with shifting losses from one person to many are derived in part from the concept of diminishing marginal utility of money, in which the injury associated with the loss of one's last dollar is considered to be marginally less than the injury associated with the loss of the second last dollar, which is less than the injury associated with the loss of the third last dollar, and so on.

7 Others have analyzed governmental liability using this functional approach. See, for example, S.H. Nahmod 'Section 1983 and the "Background" of Tort Liability' (1974) 5 o Ind. LJ 5 , at $32-3$. 
firm in which losses suffered by private individuals and firms are externalities. ${ }^{8}$ Several years ago Mark Spitzer wrote a paper on this topic in which he posited several models of state activity and analysed the incentive effects of liability rules in each case. ${ }^{9}$ In my view Spitzer's general conclusion - 'the rule which may be synthesized from all of the models is that the government should be suable in tort' ${ }^{10}$ - is supportable, if at all, only under very constrained assumptions about state activity and the operations of the review institution. If one looks only at the incentive effects of tort law on public bureaucracies, one must conclude that the optimal liability rule applicable to state action is a 'no liability' rule.

In evaluating tort law and state action it is important to recognize the contexts in which state liability may arise. Tort claims under the federal Crown Liability Act ${ }^{11}$ have been brought in respect of economic losses suffered during labour disputes, ${ }^{12}$ personal injuries in the case of care-taking responsibilities, ${ }^{13}$ economic losses in the case of alleged political patronage, ${ }^{14}$ and economic losses associated with inadequate regulation of trust companies. ${ }^{15}$ Tort law as a regulatory tool is perhaps best understood if it is considered in a limited set of bureaucratic activities. One familiar example of the intersection of tort law and government action is the losses associated with the delivery of specific kinds of public goods, such as the injuries associated with the non-delivery of police services. In order to clarify some of the ideas in this paper I will analyse the liability of the government and individual state officials for losses with reference to the enforcement of legislation by police officers. ${ }^{16}$ I have chosen this example for several reasons. First, many of the limited empirical data that have been collected on the impact of liability rules on state action describes police behaviour, and a substantial portion of the analytical and theoretical articles on government liability have dealt with police-associated injuries. ${ }^{17}$ Second, a significant number of the adminis-

8 This perspective is not common. See L. Kaplow 'An Economic Analysis of Legal Transitions' (1986) 99 Harv. $L R$ 509, at 563 .

9 M. Spitzer 'An Economic Analysis of Sovereign Immunity in Tort' (1977) 5 o So. Cal. LR 515 .

10 Ibid. 537

11 RSC 1970 , c. C-38, s. 3

12 Canadian Pacific Air Lines v. The Queen [1977] i FC 715, appeal dismisses [1979] 1 FC 39.

13 Kezar et al. v. The Queen et al. [1977] 2 wWR 83

14 Nadeau v. The Queen [1 977 ] FC 541

15 Baird v. The Queen (1983) 148 DLR (3d) 1

16 At the same time, there is no reason to believe that my assessment of liability rules and the state should be limited to the police, since most other government units share the critical characteristics which suggest that state liability should not be modelled on ideas derived from private tort law.

17 See Americans for Effective Law Enforcement, Inc. Survey of Police Misconduct Litigation 1967-1971 (Evanston, Ill. 1974), cited in E.J. Littlejohn 'Civil Liability and the Police Officer: The Need for New Deterrents to Police Misconduct' (1981) $5^{8} \mathrm{U}$. Detroit J. of Urban Law 365 , at $381-2 \mathrm{n} 86$ and accompanying text. 
trative and legislative reforms in the area of government liability have involved the police and police institutions. ${ }^{18}$ Third, the police typically engage in activities that have a private analogue, such as automobiledriving, as well as in activities that have no private analogue, such as arresting or protecting private citizens. Fourth, the police operate in relatively complex bureaucratic institutions, and the impact of liability rules is influenced by the institutional environment in which bureaucrats operate. Fifth, the police institution is easily perceived to be independent, at least to some degree, from the government. This independence may be important and is often lost sight of when discussing the liability of government departments and other sub-bureaus. Sixth, a substantial number of police liability cases have been litigated, ${ }^{19}$ and one can draw on written judicial reasons as well as case results for information on how the courts as an institution are responding to claims for compensation.

In part I of this paper I consider the appropriate 'object' of liability rules. The choices of liability 'objects' include the state (which can be liable directly or vicariously), individual bureaucrats, and a range of subbureaus within the government, including Crown corporations and departments. In the case of direct state liability, the liability rule is applied to the government, which can respond to the liability risk in any way it chooses. ${ }^{20}$ In the case of personal bureaucratic liability, the liability rule is applied to the bureaucrat, who can respond in any way she chooses. ${ }^{21}$ In

18 The most significant legislative action in this context is section 25 of the Criminal Code, RSC 1970 , C. C-34, which affords protection to police officers exercising powers under the Code if they act on 'reasonable and probable grounds.'

19 The litigation against the police falls into a range of cases. On wrongful arrest and detention, see Butt v. Saint and Loveless (1983) $3^{8}$ Nfld. \& PEIR ${ }_{15}$ (Nfld SCTD) (\$5Oo damages awarded to plaintiff who was detained by police officer without being arrested); Lang v. Burch and Carlson (1981) 8 Sask. R. 96, affd sub nom. Lang v. Burch et al. (1982) 140 DLR (3d) 325 ( $\$ 5$, ooo damages awarded to plaintiff for wrongful arrest); Romilly v. Weatherhead (1975) 55 DLR (3d) 607 (BCSC) (\$3OO awarded to plaintiff where police officers continued detention after having learned that plaintiff was not the person they suspected him to be). On actions for assault and battery, see Sandison v. Rybiak (1973) 39 DLR (3d) 366 (Ont. HC) ( $\$ 3,5$ oo awarded to plaintiff who was beaten after demanding explanation for arrest of another person. On actions for misuse of firearms, see Woodward v. Begbie (1962) 31 DLR (2d) 22, 132 CCC 145 (Ont. HC) $(\$ 518.80$ awarded to plaintiff who was shot without cause by police officer). On actions for illegal search and seizure, see Win Gat v. Johnson (1 go8) 9 WLR 293 (Sask. CA) ( $\$ 100$ awarded to plaintiff whose house was broken into by police).

20 Presumably, the response chosen by the government would maximize its welfare within constraints imposed by limited information and constitutional principles. If we are concerned with maximizing aggregate social welfare, and if we think that the government and social welfare do not necessarily coincide, then subsidiary liability rules must be developed which constrain the responses of the state to liability risks and losses.

21 Of course, it is possible to establish secondary liability rules that prevent certain responses. At the same time, it would be difficult to monitor those secondary rules. 
the case of vicarious liability, the victim must demonstrate that a particular bureaucrat committed a tort; once that threshold test is met, liability is imposed on the government without any further requirement. ${ }^{22}$ If one decides in favour of a system of liability rules, which I do not, then the optimal liability regime will impose accident costs either on the state or on the sub-units of the government, and not on individual bureaucrats.

In part II I analyse government liability; it is assumed that the activities and choices made by the relevant state actors are efficient. Under that assumption it can be argued that losses need not be internalized. Tort law is usually necessary to force private firms to take social costs into account. If the state is currently taking into account all social costs, then it does not appear to be necessary to use tort law to internalize private losses. The idea underlying government immunity is that to some extent the state will take into account the welfare of potential victims of state action. ${ }^{23}$ Bureaucratic institutions operating according to this model will make decisions that maximize social welfare, and will make those decisions whether or not they are subject to liability in tort. If the government is working perfectly, then, as is the case when markets are working perfectly, tort law is unnecessary from the point of view of efficiency analysis, and a 'no-liability' rule is optimal. In part if I also analyse government liability in the case of two different kinds of inefficient state action. In some cases the state and bureaucrats are motivated to act efficiently, but for one or more reasons they fail to do so. In other cases, the state and bureaucrats are motivated to act inefficiently. If one assumes inefficient government decisions, then an argument in favour of shifting the losses to the state can be made; but that argument holds only if one assumes, first, that the loss-internalization regime is cost justified and, second, that the state will respond to the loss-shifting in a particular manner.

In part III I explore whether and in what circumstances loss-shifting is cost-justified. I conclude that even if liability rules might appear to be an appropriate loss-internalization tool we would not necessarily choose liability rules based on models employed in the private sector. In assessing the desirability of liability rules we should be concerned with their marginal net benefits, which might be relatively small given the transaction and error costs of establishing and using court or non-court institutions and the existence of alternative loss-internalization instruments.

22 That is, vicarious state liability represents a strict liability regime once it is determined that a bureaucrat committed a tort.

23 I explore the implications of the opposite assumption - that public bureaucrats are motivated to maximize private welfare - in part $\mathrm{v}$. This assumption is widely discussed in the public choice literature. See, for example, D.C. Mueller Public Choice (Cambridge: Cambridge University Press 1979) at 148-70. 
In part IV I assess the response of the state to liability rules, and argue that it is highly unlikely that the state will respond to contingent liability risks so as to reduce accident costs in the same fashion as private firms. Thinking about the legal environment of the state necessarily involves an inquiry into the impact of liability on state action. A critical assumption behind recommendations to expand government liability is that governments react to liability rules like a private economic actor. In contrast, a 'no liability' rule is optimal when the government and bureaucratic agencies do not react to economic incentives at all. That is, only if one assumes that the state is constrained, like a private firm, by relatively efficient markets in labour, products, and capital can one predict that, ex ante, the state will react to liability risks by adopting efficient accidentreduction measures. In part Iv I analyse government liability rules in the light of the government institution's ability to pass those costs on to its constituents through self-insurance, legislative loss-shifting, and similar mechanisms. This aspect of government liability is peculiarly sensitive to the particular level of government under study. The ability of governments to shift losses to their constituents depends on the level of political competition they face, and on the particular taxing powers available to them; we can assume that, as between the market and the tax system, the state will use the latter to shift losses. Only if the effect of liability rules is the establishment of efficient systems of internal administrative discipline, can they be justified on the basis of the evaluative criterion described earlier. ${ }^{24}$

In part $\mathrm{v}$ I explore several possible liability rules that might be implemented in a subset of government activities. Even if one accepts that only the net marginal benefits of liability rules count, some might argue that there may be some general distinctions, which, while imperfect, might be relatively easily applied, and which might generate optimal rules in a limited subset of cases. For example, in the case of enterprise organizations, ${ }^{25}$ one might assume that the public enterprise will be

24 G.A. Bermann 'Integrating Governmental and Officer Tort Liability' (1977) 77 Col. LR 1175 , at 1202 . In investigating these aspects of state liability, I draw on the limited empirical data which attempt to describe the influence, if any, of current state liability on state action in Canada and the United States, and reach some tentative conclusions about the desirability of that regulatory impact. Several American studies suggest that existing liability rules have had little influence on state action. These studies can be contrasted with judicial references to the potential chilling effect of liability rules on bureaucrats. In evaluating these data it is important to remember that the bureaucracy is not a monolith, and that it may be impossible to extrapolate the preliminary findings beyond the particular bureaucracy in which they were generated.

25 By this I mean institutions, controlled by government, usually organized on a corporate model, which are engaged in delivering goods or services to the public using market mechanisms. The use of these arrangements by the government to implement public 
attempting to maximize profits, and that it should operate subject to liability rules analogous to those applicable to the private economic actors. It may be difficult, however, to distinguish between government and enterprise organizations. Even if the distinction can be made, we may want to recognize the 'public' aspect of public enterprises, and if the firm is acting as a social welfare maximizer, our model should not oblige it to internalize social costs it already has taken into account. I also explore the possibility of imposing liability on sub-units of government, but again conclude that it is unlikely that such a liability regime will itself significantly influence state action.

\section{Bureaucratic or state liability?}

Until recently, governments have not been directly liable in tort for losses associated with their activities. ${ }^{26}$ Since the Second World War, however, several national, state, and provincial governments have enacted statutes that establish a mixed system of direct and vicarious liability. Under current state-liability statutes, the federal state is directly liable to

policy grew rapidly during the post-war era. In recent years large numbers have been 'privatized,' usually through the distribution of the government's ownership interest in equity markets. The degree of government control, the extent to which the government enterprise approximates corporate models, and the extent to and the ways in which non-market considerations are permitted to influence the enterprise's decisions vary considerably from institution to institution, and there is no 'bright line' to distinguish private and public enterprises in this context. See M.J. Trebilcock and J.R.S. Prichard 'Crown Corporations: The Calculus of Instrument Choice' in J.R.S. Prichard (ed.) Crown Corporations in Canada (Toronto: Butterworths 1983).

26 To be precise, the text might read as follows: 'The Crown in Right of Canada is not, in the absence of statute, liable in tort.' For the purposes of this paper I will refer to the Canadian 'government' or 'state' instead of the 'Crown in right of Canada.'

There are few historical descriptions of government liability in Canada. The historical essays by Borchard and Holdsworth describe the English experience, which for all intents and purposes is the same as ours. See W.I.C. Binnie 'Attitudes toward State Liability in Tort: A Comparative Study' $(1964) 22$ U. Tor. Fac. of Law Rev. 88; D.W. Mundell 'Remedies against the Crown' in Remedies (Special Lectures of the Law Society of Upper Canada, 1961) 149; B.L. Strayer 'Crown Immunity and Judicial Review' in O.E. Lang (ed.) Contemporary Problems of Public Law in Canada (Toronto: University of Toronto Press 1968) at 71 ; W. Mueller 'The Liability of the Ontario Government in Tort' (1967) 25 U. Tor. Fac. of Law Rev. 3; W.S. Holdsworth 'The History of Remedies against the Crown' (1922) 38 Law $Q R$ 141, at 280; and E. Borchard 'Government Liability in Tort' (1948) 26 Can. Bar Rev. 399.

The immunity is often incorrectly attributed to the application of the maxim 'the King can do no wrong.' See M. Aronson and H. Whitmore Public Torts and Contracts (Sydney: Law Book Co. 1982) at 1. Other conclusory reasons include the alleged absence of jurisdiction over the sovereign offered by Locke $\mathrm{J}$ in $C B C \mathrm{v}$. Attorney General for Ontario [1959] SCR 188, at 204, and the Holmesian logic that there can be no legal right as against the authority that makes the law on which the right depends, which Holmes J expressed in Kawananakoa v. Polyblank 205 U.s. 349, at 353 (1907). 
compensate a limited class of plaintiff's in cases of damage sustained while on federal government property, or as an employee of the federal government. In all other cases, which comprise the vast majority of claims and the greatest percentage of losses, government liability is vicarious. ${ }^{27}$ In this latter category liability is imposed jointly and severally on the state as an institution and on individual bureaucrats; ${ }^{28}$ a prerequisite to state liability is the commission of a tort by an individual civil servant.

The choice of this liability regime has an important impact on the ability of the tort system to internalize social costs. To the extent that accidents are associated with institutional activities - that is, the planned, coordinated, and structured actions of numbers of individuals in the context of achieving governmental objectives - the retention of a vicarious liability model makes it impossible to shift losses to the state. ${ }^{29}$ Many injuries apparently associated with an individual bureaucrat result from 'systemic problems' within the bureaucratic agency,,$^{\circ}$ and imposing liability at the lowest level of the organization may not be an effective means of modifying institutional behaviour. ${ }^{3^{1}}$ Similarly, if it is impossible to determine the identity of a bureaucrat who committed a tort, accident losses will be externalized.$^{32}$ Moreover, to the extent that uncompensated litigation costs are associated with the requirement that the plaintiff

27 For example, under section $3^{(1)}$ of the federal Crown Liability Act, RSC 1970, c. C- 38 , the federal government is liable directly for breahces of common law duties associated with the ownership and occupation of property, for breaches of common law duties associated with its status as an employer, and for statutory torts. It is vicariously liable in respect of a tort committed by a servant of the Crown' under the same section. Section $4(2)$ confirms that liability cannot be imposed unless an individual bureaucrat is found to be personally responsible.

28 The federal government Claims Regulations, CRC 1978 , c. $68_{3}$, s. 14, specifically outline the factors determining when and the extent to which the government can, in effect, 'claim contribution' - that is, be reimbursed by the public servant for the cost of her torts.

29 This important limiting concept is also apparent in the law of nuisance, where the courts have demanded that a loss be 'actionable at common law' before they will impose liability on public institutions. See Caledonian Rwy v. Ogilvy (1856) 2 Macq. 229 (HL) and The Queen v. Loiselle (1962) 35 DLR (2d) 274 , at 276 (sCc).

3o It has been argued, for example, that 'abuses of prosecutorial authority are not inherent in discretion; rather, they are contingent upon the context and manner in which discretion is exercised.' See P.J. Utz 'Two Models of Prosecutorial Professionalism' in W.F. McDonald (ed.) The Prosecutor (Beverly Hills: Sage Publications 1979) 119. The injuries suffered by private citizens are associated with the institution's structure and operations. As Owen Fiss has said, the 'wrong is the structure itself,' and thus the remedy must be directed at the structure to prevent the continuation of the injury. See O.M. Fiss The Civil Rights Injunction (Bloomington: Indiana University Press 1978) at 11.

31 See 'Developments in the Law - Section 1983 and Federalism' (1977) 9o Harv. LR 1133 , at $1218-19$.

32 See D.H. Jack 'Actions against the Crown' in Suing the Government - A Conference Report (Toronto: Insight Educational Services 1981) 26 . 
demonstrate personal bureaucratic liability, fewer lawsuits will be undertaken, ${ }^{33}$ and as a plaintiff's expected litigation costs increase the expected value of the lawsuit must increase to justify her investment. ${ }^{34}$

Judges have reacted to this difficulty by imposing vicarious liability on the state for the torts of groups of bureaucrats ${ }^{35}$ and by imposing liability when 'there is a reasonable case of action in tort against one [bureaucrat $]^{36}$ but there is a considerable risk that an inability to pierce the 'black box' of the bureaucratic state will substantially reduce the likelihood of successful lawsuits. For example, it is difficult to conceive of a personal liability regime dealing with the inadequate servicing of penal facilities, with allegedly excessive security measures in municipal jails, ${ }^{37}$ with systemic police brutality, ${ }^{38}$ and with injuries associated with racial discrimination. ${ }^{39}$ Moreover, simply imposing vicarious liability does little to solve this problem, since identification of the individual bureaucrat who committed a tort is a costly and difficult (if not an impossible) task..$^{\circ}$

The difficulties associated with using personal bureaucratic liability to internalize institutional wrongs are magnified by common law rules that preclude the imposition of vicarious liability on Crown corporations, federal administrative agencies, and superior officers for the torts of subordinate federal civil servants. ${ }^{41}$ An empirical study conducted in

33 Judges have suggested that in the absence of an explanation from the government of the rationale for and the details of the decision-making process that gave rise to the injury, they will presume that the government acted in an operational capacity and thus, at least on this variable, is liable in negligence. See Kamloops v. Nielsen, supra note 2.

34 The problem is exacerbated if the losses suffered by individual victims of state action are relatively small, in which case, unless procedural modifications are employed to permit the aggregation of claims, the individual plaintiff will not be motivated to sue.

35 See Nadeau v. The Queen, supra note 14.

36 See Stephens v. The Queen (1982) 26 CPC 1 (FCA) (action against the Crown in federal court; court does not have jurisdiction against individual bureaucrat).

37 See Morgan v. Superintendent of Winnipeg Remand Centre et al. [1983] 3 WWR 542, at 557-8, appeal dismissed (1983) 29 Man. R. (2d) 55 .

$3^{8}$ Build of Buffalo v. Sedita 441 F. 2 d 284 ( 2 d Cir. 1971) (action by citizens of Buffalo asking for injunctive relief against police commissioner, the city, and individual police officers).

39 See Rizzo v. Goode, 423 U.s. 362 (1976). In this case the Supreme Court denied injunctive relief, apparently on the grounds that there was no pervasive pattern of mistreatment. The trial court had issued an order requiring the defendants to revise their existing citizen-complaint procedures. See COPPAR v. Rizzo, 357 F. Supp. 1289 (1973).

40 Thus, institutional torts can be conceived of as injury-causing activities for which responsibility cannot be allocated to one person. The term may also refer to losses in situations in which individual actors are not identifiable within an organization.

41 Viscount Canterbury v. Attorney General (1842) i Ph. 306 at 324; Quebec Liquor Commission v. Moore [1924] SCR 540, at $55^{1-2}$. This difficulty applies even in the corporate context, with the result that Crown corporations often will not be vicariously liable for the torts of 'their' employees. The courts have held that both the corporation and the employees 
Connecticut in the late 197os suggests that the same phenomenon will result even in the absence of judicially created immunities. That study examined the impact of 'constitutional tort damage claim' on the conduct of police officers..$^{2}$ Apparently, superior officers were not appreciably affected by the legal actions brought against their subordinates. Of the 149 cases studied, superior officers were never found liable for the constitutional violations of their line officers, were joined in only 82 suits, and were defendants at trial in only 9 cases. ${ }^{43}$

Vicarious liability (and thus a requirement of personal bureaucratic responsibility) has adverse effects on the ability of the tort system to internalize losses for other reasons. Possibly the most important is the exclusion of all losses that are not currently subject to regulation in the private tort law system. ${ }^{44}$ It is fair to say that pure economic loss is only imperfectly recognized in current private tort law doctrine. ${ }^{45}$ This partial recognition of interests has two undesirable aspects. First, using a vicarious liability regime will externalize losses to the extent that the tort system does not recognize the interest. Second, bureaucratic behaviour, if it is influenced at all, will systemically respond only to litigation risks in a subset of cases. The resulting distortions in bureaucratic behaviour can hardly be optimal.

Losses may also be externalized because injuries caused by public institutions have no private analogue to which tort law has traditionally been applied. Losses associated with paradigmatic state action including policing, enforcement of statutes, delivering educational benefits, and paroling prisoners will not be allocated to the state under any model that simply transposes private tort law and applies it to individual bureaucrats. ${ }^{46}$ Finally, the state is often engaged in delivering private and public

are Crown employees for whom the Crown can be responsible, but that neither is responsible for the torts of the other. See Bainbridge v. Postmaster General [1 1906] 1 кв 178, at 191; Roper v. Works and Buildings Commissioners [1915] $1 \mathrm{~KB} 45$; and McLean v. Vancouver Harbour Commissioners [1936] 3 wWR 657 (BCSC)..

An interesting exception to this doctrinal rule is the American decision in Carter v. Estelle, $5^{19}$ F. 2d $113^{6}$ ( $5^{\text {th }}$ Cir. 1975), in which prison administrators were held vicariously liable for the acts of prison employees.

42 See Project 'Suing the Police in Federal Court' (1979) 88 Yale LJ 781.

43 Ibid. $811-12$

44 This point is developed more fully in D. Cohen and J.C. Smith 'Entitlement and the Body Politic: Rethinking Negligence in Public Law' (1986) 64 Can. Bar Rev. 1.

45 Ibid. Until Junior Books Ltd v. Veitchi Co Ltd [1983] 1 AC 520, [1982] 3 All ER 201 (HL), it was unlikely that a person whose only injury was financial could successfully persuade a judge to shift the loss to another person.

46 The government is often engaged in activities that have no private counterpart. In these cases losses may not be recognized simply because it is impossible to point to a tort committed by the civil servant. 
goods through non-market instruments. The reluctance of judges to recognize positive duties of beneficence between private individuals, coupled with the requirement of personal bureaucratic responsibility, means that losses associated with the non-receipt of government benefits will be internalized only in a small percentage of cases. ${ }^{47}$

A third attribute of personal bureaucratic liability that may be associated with loss-externalization is the focus of judicial review on individual bureaucrats. It may be that the requirement that an individual bureaucrat be identified in the lawsuit means that the decision-maker will be forced to focus her attention on a specific person, perhaps giving rise to a bias towards the defendant - especially in the case of institutional plaintiffs. This elusive built-in bias is exacerbated by rules that preclude the disclosure of insurance and indemnification arrangements which might effectively shift the economic risks of liability to the state institution with which the bureaucrat is associated. Even here, however, the bias in favour of individual bureaucrats may reflect judicial notions of fairness an implicit understanding that the injury will only rarely be associated with the activity of an individual bureaucrat, and that while the economic risks of litigation may be shifted, the individual bureaucrat may face other costs..$^{8}$

Individual bureaucratic liability may be suboptimal as a loss-internalization technique for other reasons. A particular bureaucrat will often be responsible for losses that exceed her personal wealth. Leaving aside issues of compensation, the bureaucrat will be indifferent to potential liability for losses exceeding the value of her personal assets. ${ }^{49}$ In fact, she may have an incentive to expend public resources on reducing the risk of losses of a magnitude that might affect her personal wealth rather than on reducing the risk of accidents in excess of that level..$^{\circ}$ Thus, to the extent that we are concerned about the internalization of significant losses

47 I have recently argued that the limitation on recovery of losses associated with non-receipt of government benefits should be modified. See Cohen and Smith, supra note 44 .

$4^{8}$ The emphasis on the individual defendant in cases of substantial public exposure may cause the public to see the 'defendant official as a wrongdoer who has committed a particularly offensive act ... rather than as a stand-in for his government employer.' $\mathrm{C}$. Whitman 'Constitutional Torts' (1980) 79 Mich. LR 5 , at 57-8.

49 J.P. Murphy 'Is the Municipality Liable for Insufficiently Trained Police?' University of Maine Bureau of Public Administration (1968) 21 ; S. Rose-Ackerman 'Reforming Public Bureaucracy through Economic Incentives? no wsrv-12 Law and Economic Workshop Series, University of Toronto 1986,25

$5^{\circ}$ That is, if she is given a choice between spending one dollar to reduce expected accident costs from say, $\$ 1,000,000$ to $\$ 500,000$, and spending the same dollar to reduce expected accident costs from $\$ 20,000$ to $\$ 10,000$, a bureaucrat with a net worth of \$200,00o probably will choose the latter, less efficient, alternative. 
associated with state action, personal bureaucratic liability will have little impact on bureau behaviour. ${ }^{1}$

Personal bureaucratic liability is also likely to generate less than optimal responses because of the environment in which individual bureaucratic decisions are made. Police officers who are faced with discretionary choices while engaged in law enforcement activities in which their lives and safety are threatened are hardly likely to engage in a cost-benefit analysis that might generate efficient law enforcement behaviour. Their uncertainty of the location of the liability line and the limited time in which the decision can be made both suggest that personal police decision-making behaviour ought not to be the object of 'tort regulation. ${ }^{52}$ Moreover, the inability of an individual police officer to assess factors outside of her immediate environment, and the lack of any incentive to do so given the individual focus of the liability rules will lead to decisions that minimize personal risk and perhaps externalize losses away from individual bureaucrats. Those decisions may bear no relation to decisions that minimize risks across all bureaucratic activities.

Although the application of liability rules that demand personal bureaucratic liability will result in the externalization of some losses, it may also lead to the opposite result. The requirement that an individual bureaucrat be found liable in tort may be associated with over-deterrence - that is, with excessive accident-reduction responses by the bureaucracy. If bureaucrats misperceive legal risks associated with regulatory action, over-deterrence may take the form of less than optimal regulatory activity and excessive loss-prevention measures. ${ }^{53}$ Alternatively, personal liability rules may generate more than optimal regulation if the perceived risks relate to regulatory inaction. On the assumption that judges rarely impose positive obligations on the state, one can confidently predict the former response. ${ }^{54}$ The argument that some bureaucrats will respond in an inappropriate fashion to threats of personal liability may be especially

$5^{1}$ One can also argue that personal liability rules encourage decentralization as a response to potential personal liability risks. If the decentralization would not have occurred otherwise, one can legitimately question its desirability.

$5^{2}$ See Prior v. McNab (1976) 78 DLR (3d) 319 , at 327 (Ont. HC), in which these factors were offered in support of not imposing liability on police officers who must 'frequently act hurriedly and react to sudden emergencies.'

53 This argument was accepted by the Supreme Court of the United States in justifying the granting of absolute immunity to President Richard Nixon from damage suits in the case of constitutional violations. See respondents' brief in Nixon v. Fitzgerald 457 U.s. 731,102 St. Ct. 2690 (1982), discussed in A.A. Orenstein 'Presidential Immunity from Civil Liability' (1983) 68 Comell LR 236, at 250.

54 I am assuming that the bureaucrat cannot shift the loss to the state either ex ante or ex post. To the extent that insurance is available, the risk of under-regulation is reduced. 
relevant when the bureaucrat is likely to be cognizant of legal sanctions ${ }^{55}$ and when she is easily identifiable..$^{6}$

There are several reasons to predict that bureaucrats will act in inefficient ways when faced with perceived risks of personal liability. There is some evidence that as a class bureaucrats are substantially more risk-adverse than the population as a whole. ${ }^{57}$ Assuming that they will bear risks personally, they will react by refusing to implement their regulatory responsibilities, delaying implementation, or engaging in defensive litigation strategies - that is, building a record in anticipation of lawsuits. In all cases we can anticipate inefficiencies. Further, underregulation will be produced as a result of the substantial asymmetrical incentives associated with lawsuits as a regulatory device in the case of public wrongs. Where bureaucratic remuneration is independent of the social benefits the bureaucrats produce, officials who bear the risks of losses associated with their behaviour ${ }^{58}$ will not be able to capture the benefits. ${ }^{59}$ This will be so even if we hypothesize some kind of windfall gains tax to internalize benefits at the governmental level. ${ }^{60}$ Certainly one can anticipate that bureaucrats will be rewarded through increased remuneration, promotions, and the like when they demonstrate that they are fulfilling their regulatory responsibilities; and to the extent that they are, one can argue that they are personally capturing some of the social benefits associated with their actions. ${ }^{61}$ None the less, it is unlikely that the

55 The concern is most commonly voiced in the context of prosecutorial immunities. See Gregoire v. Biddle et al. 177 F. 2d 579 (1949) and Owsley v. R. in Right of Ontario (1983) 34 CPC 96 at 101 (Ont. HC)..

56 Nixon v. Fitzgerald, supra note 53,2703 (S. Ct.)

57 P.H. Schuck Suing Government: Citizen Remedies for Official Wrongs (New Haven: Yale University Press 1983) at 57, 70; D. Bellante and A.N. Link 'Are Public Sector Workers More Risk Averse Than Private Sector Workers?' (1981) 34 Industrial \& Lab. Rel. Rev. 408

$5^{8}$ This phenomenon is independent of the standard of care established for official liability. Michael Trebilcock and Jack Quinn made this point in 'Compensation, Transition Costs, and Regulatory Change' (1982) 32 UTLJ 118, at 131-2. The incentive structures that bureaucrats face are likely to lead to decisions that disfavour compensation.

59 As Richard Posner put it, 'There is thus an imbalance: zealous polic officers bear the full social costs of their mistakes through the tort system but do not receive the full social benefits of their successes through the compensation system.' See R.A. Posner 'Excessive Sanctions for Governmental Misconduct in Criminal Cases' (1982) 57 Wash. $L R 635$, at 640 ; R.A. Posner 'Rethinking the Fourth Amendment' [1981] Sup. Ct. Rev. 49 , at 65 ; J.L. Mashaw 'Civil Liability of Government Officers: Property Rights and Official Accountability' (1978) 42 Law \& Contemp. Prob. 8, at 26-7.

60 See Kaplow, supra note 8,570 .

61 It seems unlikely that bureaucrats could receive remuneration in the form of shares or options representing a proportion of tax revenues, or increases in gross national product. None the less, if bureaucrats could be paid on a 'piece-work' basis, under 
anticipated gains in any way approximate the perceived risks of personal liability. ${ }^{62}$

The asymmetry is exacerbated by the doctrinal rules described earlier, which make it difficult if not impossible to sue bureaucrats when they remain passive. Thus, when a bureaucrat fails to act she can anticipate that the persons injured as a result of her passivity, even if they can identify themselves or be identified, will not sue; and if they do, they probably will not succeed. ${ }^{63}$ Conversely, victims of state action are easy to identify, and are likely to attempt to obtain compensation when the losses are highly focused. ${ }^{64}$ The problem is well recognized in cases of regulatory action, where the victims are diffuse and unorganized and the beneficiaries are highly focused. In the case of threatened litigation the skewed incentives will give rise to inaction.

Attempts to respond to the problem of skewed incentives can take various forms, none of which is entirely satisfactory from the point of view of accident-reduction analysis. First, it is common to enact 'tort privative clauses' that provide that a particular bureaucrat is not personally responsible for losses associated with her actions. ${ }^{65}$ Moreover, judges have

which they would receive remuneration determined by the net social benefits they produced, tort law would be unnecessary.

62 The logic of this argument might lead one to conclude that direct state liability is optimal, since the state (in the sense of the individuals who are members of the relevant community) will obtain the benefits associated with state action, and thus will not have their choices biased against action. The problem with that argument is that the community does not make the decisions giving rise to the injury, nor are the benefits of state action allocated equally among all citizens.

$6_{3}$ Lawsuits that seek compensation for bureaucratic inaction are unlikely to succeed because the liability of governments and bureaucrats is modelled on private liability. As a general rule, judges have been reluctant to impose liability on individuals for failures to assist others; and when this idea is transposed to the public sector, bureaucrats are rewarded for inefficient passivity as compared with inefficient action. See Cohen and Smith, supra note 44

64 See Butz v. Economou $43^{8}$ u.s. $478,5^{1} 5$ (1978).

65 In addition to the Criminal Code immunity, police are protected when they exercise enforcement powers under provincial legislation in a number of provinces. In Ontario the Public Authorities Protection Act, RSo 1980, c. 4o6, grants extensive immunity to a range of public servants who commit torts in the course of carrying out their public duties. See Colledge v. Niagara Regional Police Commission (1984) I OAC 23 (the act does not apply to internal disciplinary proceedings under the Police Act); Berardinelliv. Ontario Housing Corporation [1979] 1 SCR 275, (1979) 90 DLR (3d) 481 (the act applies only to public and statutory responsibilities).

In Saskatchewan, police are afforded a 'good faith' immunity under the Police Act, RSS 1978 , C. P- 15 , s. 19 , and the Summary Offences Procedure Act, RSS 1978 , c. s-63, s. 7 . These sections were applied in Carr v. Forbes et al. (1980) 7 Sask. R. 123 (Sask. QB), Morrissette and Morrissette v. Salagubas and Hosaluk (1984) 32 Sask. R. 25 (Sask. QB), and Lang v. Bruch and Carlson (1982) 18 Sask. R. 99 (Sask. CA).

There are innumerable statutes providing for bureaucratic immunities in particular 
established additional analogous common law immunities. ${ }^{66}$ In one recent case, bureaucratic immunities were justified on the utilitarian argument that the externalization of losses was necessary 'for the advancement of the greater public good' in view of the potential impact of exposing bureaucrats to the risk of personal liability. ${ }^{6}$ While these statutory and judicial immunities are likely to be adequate in rebalancing the incentives faced by some groups of bureaucrats, they have the secondary effect of insulating the state from responsibility as well. A decision to immunize the bureaucrat under current vicarious liability rules may preclude the allocation of the loss to the state. ${ }^{68}$

Another response to potential personal liability risks is the enactment of 'legal defence' statutes, which provide that the state must furnish individual bureaucrats with legal representation or compensate them for

situations. See Wildlife Act, RSBC 1979, C. 433, s. 8o(3), and Diversified Holdings Ltd v. R. in Right of $B C$ [1983] 2 WWR 289 (BCCA). These statutes commonly insulate bureaucrats from liability when they act in 'good faith.' See Trade Practice Act, RSBC 1979, c. 4o6, s. 16(1), and Liquor Control Act, RSA 1980, c. L-17, s. 77(4).

66 The immunities that are judicially created are enjoyed for the most part by state officials engaged in judicial or quasi-judicial activities. The most notorious of these are the absolute immunities enjoyed by judges and Crown prosecutors. See Bosada v. Pinos (1984) 44 OR (2d) $789,(1984) 5$ DLR (4th) 334 (Ont. HC), and Richman v. McMurtry (1983) 147 DLR ( $3 \mathrm{~d}$ ) 748 (Ont. HC). The prosecutorial and judicial immunities were recognized soon after Confederation: see The Queen v. McLeod (1883) 8 SCR 1, at 26. In Ontario these judicial immunities are established under the Proceedings against the Crown Act, RSO 1980 , c. 393 , ss. 2(2)(d) and 5 (b). See also Owsley v. R. in Right of Ontario (1983) 34 CPC 96, at 101 (Ont. HC). Compare Nelles v. The Queen in Right of Ontario (1985) 51 OR (2d) 513 , at 530,23 CCLT 291, at 312 (Ont. CA), rev'd in part by (1989) 6o DLR (4th) 609 (sCC).

American courts have adopted similar immunities for judicial officers, justifying the externalization of losses on the ground that judges would be over-deterred by the threat of liability. See Pierson v. Ray 386 u.s. 547 ( 1967$)$, and Stump v. Sparkman 435 U.S. 349 , at $355^{-6}(1978)$. In addition, American courts have extended these immunities to senior officials within the executive branch of government. See Sparling v. Vilas 161 U.s. 483 (1896), and Barr v. Matteo 360 u.s. 564 (1959). Recently, absolute immunity was extended to the President of the United States, even in the case of constitutional violations; see Nixon v. Fitzgerald 102 S. Ct. 2690 (1982).

67 Richman v. McMurtry (1983) 147 DLR (3d) 748, at 753 (Ont. HC). A similar utilitarian justification was offered by Judge Learned Hand in Gregoire v. Biddle 177 F. 2d 579, at $5^{81}$ (1949).

In Scheuer v. Rhodes 416 U.S. 232, at 240 (1974), the American Supreme Court granted 'good faith' immunity to state officers faced with constitutional 'tort' liability in light of 'the danger that the threat of such liability would deter his willingness to execute his office with the decisiveness and the judgment required by the public good.'

68 This does not have to be the case, since it is possible to establish personal bureaucratic immunity and couple it with direct state liability either on a respondeat superior basis or on theories of enterprise liability. See R.A. Posner 'Rethinking the Fourth Amendment' [1981] Sup. Ct. Law Rev. 49, at 67-8. See also Norton v. United States $5^{81}$ F. 2d 390 (4th Cir. 1978). 
legal expenses, ${ }^{69}$ thus reducing marginally the risks associated with liability rules. Alternatively, the government may enact insurance statutes that require government agencies to carry insurance for particular officers for liability incurred in the performance of their official responsibilities. Finally, the government may enact indemnification statutes that require agencies to pay damage awards ordered against an individual bureaucrat. In both cases the effect is to make the government the insurer of its employees' liability risks and thus to shift the regulatory impact away from the individual. The federal government employees' union apparently has not considered it necessary to obtain such provisions as a term of employment, ${ }^{70}$ although indemnification takes place as a matter of practice. Given the inability of bureaucrats to diversify the risks of personal liability, and in the light of the obvious fact that the risk of legal liability to the 'owners' of the state is diversified across the entire tax-paying population, one can predict substantial advantages to both parties through risk-shifting arrangements as an aspect of the employment relationship. ${ }^{71}$

A possible private solution to the skewed incentives associated with personal liability is the creation of a private market in 'bureaucratic liability' insurance. Such insurance markets have developed to a limited degree in some jurisdictions, but not in Canada..$^{2}$ Given the inexperience of insurance companies with running governments, the costs of acquiring information about the enterprise whose activities are associated with the risks it is expected to insure, and the costs of monitoring the insured's activities, the failure of a private insurance market to develop fully is not surprising; and even if insurance markets could take into account the uncertainties associated with public activities, the provision of the public insurance programs described above settles the question.

Yet it is not at all certain that even these arrangements are sufficient to

69 The array of possible insurance, indemnification, and similar arrangements is limited only by the imagination of contract drafters, and the creation of mutual expected benefits associated with shifting risks from individuals to a larger community. The discussion in the text is a brief synopsis of the American experience described in M.G. Yudof 'Liability for Constitutional Torts and the Risk-Averse Public School Official' (1976) 49 So. Cal. LR 1322, at 1383-8.

70 This arrangement appears to be typical of public institutions in the United States. See Monell v. New York City Department of Social Services 436 u.s. 658, at 713 (1978), and 'Suing the Police in Federal Court,' supra note $42,785,810$ et seq.

71 R.H. Kraakman makes this point persuasively in the context of private firms, but it seems to me that it is equally applicable to public bureaucracies. See 'Corporate Liability Strategies and the Costs of Legal Controls' (1984) 93 Yale LJ 857, at 864-7. What is interesting about Kraakman's ideas is that they predict institutional liability only, unless personal liability adds substantially to our regulatory objectives.

72 See Yudof, supra note 69,1385 . 
overcome the skewed incentives. First, there is the uncertainty associated with determining whether the particular activity associated with the loss comes within the insurance coverage. Moreover, it is possible that some risks may be uninsurable. ${ }^{73}$ More important, the costs associated with a lawsuit brought against an individual bureaucrat may include emotional trauma, employment disruptions, and associated non-monetary losses; ${ }^{74}$ these would not be covered by liability insurance, which indemnifies only for awards to plaintiffs.

Insurance or alternative risk-shifting arrangements may be less than optimal for other reasons. Vicarious liability or personal liability with insurance in all cases will result in the inappropriate shifting of losses to the state in the case of the 'rogue' bureaucrat, who, using the authority of her office, deliberately inflicts injury on a particular firm or individual for personal gain. Roncarelli v. Duplessis ${ }^{75}$ is perhaps the best known of these cases, but corruption is not an entirely foreign idea in public bureaucracies. If a state official is insulated from liability under private risk-shifting arrangements even when she acted in her personal interest, we will be faced with a substantial risk of externalization of losses.

For all these reasons, personal bureaucratic liability, whether or not it is coupled with insurance, does not appear to be a desirable starting-point in designing optimal government liability rules. ${ }^{76}$ The optimal liability regime, assuming that a liability regime is desirable at all, appears to be direct

73 See R.J. Weddle 'Damages under S. 1983: The School Context' (1971) 46 Ind. LJ 521 , at 535, and Peoria v. Underwriter's at Lloyd's London, Unicorp 290 F. Supp. 890 (1968). It is against public policy, of course, to insure oneself against the consequences of a criminal act. The courts have broadly interpreted insurance policies, and the scope of negligent behaviour that can be insured against is wide. See Tinline v. White Cross Insurance Association [1921] 3 KB 327 (insured guilty of manslaughter in driving of motor vehicle held to be covered by policy); compare O'Hearn v. Yorkshire Insurance Co. (1921) $5_{1}^{1}$ OLR 130 (Ont. CA) (insured who killed a man while driving drunk not indemnified for the criminal act). Under the Insurance Act, RSo 1980, c. 218 , s. 95, a violation of criminal law no longer automatically renders unenforceable a claim for indemnity. The burden of proof is on the insurer to demonstrate that the acts were criminal, and the activity must be characterized as immoral. See American Auto Insurance Co. v. Dickson [1943] SCR 143 .

74 'Suing the Police in Federal Court' supra note 42, 809-1 1; Yudof, supra note 69, 1390.

75 [1959] SCR 121, 16 DLR (2d) 689. (Similar claims have been made in Gershman v. Manitoba Producers' Marketing Board (1976) 69 DLR (3d) 114 (Man. CA)). By the term 'rogue bureaucrat' I mean the bureaucrat who is motivated by personal greed and acts in such a way that no public benefit is associated with her action.

76 It should be obvious by now that the arguments against personal bureacratic liability apply with nearly the same force to 'private' bureaucrats employed by large corporations. While there is no fundamental difference between the two bureaucracies, there may be differential effects relating to the particular regulatory responsibilities of public bureaucrats, which should genereate positive obligations to benefit the public, and to the likelihood that performance-linked wage rates could be instituted in the public sector. 
state liability. Under this model of liability a person injured as a result of state action ${ }^{77}$ would simply claim and obtain compensation from the state, leaving that institution to develop efficient responses in view of its exposure to accident risks.

The abrogation of personal bureaucratic liability and its replacement with state liability raises subsidiary issues that must be resolved in order to predict its impact on government-generated accidents. In particular, we must choose between state liability based on the doctrine of respondeat superior in which personal bureaucratic liability remains a prerequisite to liability but is coupled with personal immunity or a prohibition on a right to employer indemnification, ${ }^{78}$ and direct state liability in which it is unnecessary to demonstrate a civil wrong committed by an individual bureaucrat. Leaving aside the advantages of either system from a compensation perspective, the direct state liability model appears, at first glance, to reduce litigation costs and thus to increase the likelihood that actions against the state will be cost-justified. To the extent that enforcement costs are reduced, resulting externalities are avoided. Furthermore, direct state liability reduces concerns with the exposure of state bureaucrats to the non-compensable risks of litigation, ${ }^{79}$ reduced the distortions associated with pro-defendant bias, and enables the tort system to deal with institutional wrongs.

But a direct liability regime is not necessarily an effective method to regulate state accident-related activity. Its desirability depends on a range of subsidiary issues. First, we must consider what it means to review the state: we will, it seems, be forced to determine which state actors will be considered to personify the state for the purposes of liability rules: to what extent is it possible to identify individuals, institutions, and activities whose conduct we can say is state conduct for the purposes of liability rules? Second, the decision to adopt a direct liability regime will rest, in part, on our assumptions regarding the current efficiency of state decision. Finally, the advantages of a direct liability regime will depend on the response of the state to the liability rules. (These issues are discussed later in this paper.)

The final point in any proposal to adopt direct liability regime is to

77 That idea must be qualified in two important ways. First, one still has to define 'state action,' which would exclude a wide range of redistributive activities that would be undercut by compensation mechanisms; taxes are the most obvious examples, but redistribution is achieved through a wide range of instruments. Second, one has to differentiate between state actors acting in their personal and official capacities.

$7^{8}$ This is the model utilized by Posner in 'Rethinking the Fourth Amendment' supra note 59 .

79 An excellent discussion of the direct liability model of state liability is contained in Bermann, supra note 24, 11 94-1202. 
consider whether it is appropriate to retain personal bureaucratic liability. The discussion of the adverse effects of personal liability suggests that the answer is no. Yet one might argue that if we adopt a system of enterprise liability, we must retain personal bureaucratic liability unless the state reacts to the liability rules in the same manner as a private firm. That is, if the state is not responding to liability rules, but is simply shifting them to the tax-paying public, then personal bureaucratic liability is the only effective regulatory tool we have. If the legal system cannot charge a price high enough to deter the state's injury-causing activity, there is at least an argument in favour of retaining personal liability. ${ }^{80}$

As I suggested earlier, a further problem with enterprise liability is the inappropriate shifting of losses to the state in the case of rogue bureaucrats. ${ }^{81}$ If we believe that these types of injuries are engaged in by a small number of bureaucrats who are not identifiable ex ante at a reasonable cost, and whose activities in this context are not easily monitored, personal bureaucratic liability with risk-shifting prohibited by law appears to be the optimal regime. ${ }^{82}$ However, the argument that we ought to retain personal liability in the case of bureaucrats who are motivated by personal gain is meaningful only if we impose personal liability coupled with subsidiary rules that prohibit loss-shifting to the state. For the reasons set out earlier that is unlikely, and in any case would generate substantial costs. ${ }^{83}$

\section{The efficiency of state action}

THE EFFICIENT STATE

Using tort law to generate economic signals and thus to provide incentives to the state to internalize losses suffered by private firms individuals necessarily involves an analysis of the efficiency of the bureaucratic decision associated with the loss. The economic rationale for loss internalization to private firms is that the production function of private firms will reflect only private costs. Thus, tort law is necessary to force the

8o The point is made by Kraakman, supra note 71,876 , who refers to this idea as 'sanction insufficiency.' He recognizes that if sanction insufficiency is the rationale for personal bureaucratic liability, then risk-shifting must be prohibited.

81 See K. Kernaghan 'The Ethical Conduct of Public Servants' in K.M. Gibbons and D.C. Rowat (eds) Political Corruption in Canada (Toronto: McClelland and Stewart 1976) at 158, and A.A. Rogow and H.D. Laswell 'The Definition of Corruption' in A.J. Heidenheimer (ed.) Political Corruption (New York: Holt Rinehart Winston 1970) at 54 .

82 I admit that ex ante risk-shifting through contract wage modifications and similar means would be difficult to monitor.

83 These costs would include the error costs in false positives, and the adverse incentive affects that risk would present to bureaucrats. 
private firm to take into account social costs; if it does, its production decisions will be optimal. If one makes the heroic assumption that the state is currently taking into account all social costs, then it does not appear to be necessary to use tort law to internalize private losses ${ }^{84}$ One idea underlying government immunity is that, to some extent, the state will take into account the welfare of potential victims of state action and that, when it does, judges cannot effectively review those decisions. ${ }^{85}$ Bureaucrats and bureaucratic institutions that operate according to this model will make decisions that maximize social welfare, and will make those decisions whether or not they are subject to tort liability. ${ }^{86}$ If the government is working 'perfectly,' then, as when markets are working perfectly, tort law is unnecessary from the point of view of efficiency analysis, and a 'no liability' rule is optimal.

However, an assumption that government is motivated to achieve social allocative efficiency does not necessarily mean that we should never impose liability for losses associated with state action. Rather, it suggests that we ought to engage in a review process that investigates whether a particular bureaucratic decision, set of decisions, or institutional structure accurately identifies a socially optimal choice and then implements the choice in an efficient manner. If we find that the government, though properly motivated, did not in fact achieve a potentially Pareto-optimal outcome, we ought to impose liability. ${ }^{87}$ This should be so even if the outcome was potentially Pareto-superior. In all cases, except for the Pareto-optimal decision, liability rules will have the effect of ensuring that the government takes into account all the costs associated with decisions that do not maximize social welfare. ${ }^{88}$

84 In fact, if we were to do so, without more, we would run the risk of 'double-costing' the losses, with an associated under-production of the regulatory goods.

85 See W.F. Baxter 'Enterprise Liability, Public and Private' (1978) 42 Law E Contemp. Prob. 45, at $5^{\circ}$.

86 See Spitzer, supra note $5,5^{25}-6$.

87 It should be obvious that my analysis focuses only on non-redistributive decisions of the state. It is not that I deny either the reality or desirability of redistribution, but rather that I am assessing the allocative and not the distributive implications of liability rules.

88 There are several reasons which suggest that we ought to impose liability unless the decision was Pareto-optimal. First, as long as the court is examining government action for efficiency, there seems no reason that Pareto-superiority should be the test, since Pareto-optimality maximizes rather than simply improves welfare. If Pareto-optimal choice can be determined in the particular case, the government should be induced to act in that fashion.

Second, using a standard of Pareto-superiority could have devastating effects on equality and democracy. Pareto-superiority is value-blind in that as long as no person is worse off, it is irrelevant who is made better off. A standard of Pareto-superiority could allow for large variation in the relative wealth of groups, and exacerbate rather than mitigate distributional consequences.

Third, a false misfeasance-nonfeasance distinction may arise here. The standard of Pareto-superiority might be taken to imply that the government should be liable to 
THE INEFFICIENT STATE

The inefficient state can be visualized in two ways. In the first (case 1), state institutions and bureaucrats are motivated to act efficiently but for one or more reasons fail to do so. In the other (case 2), state institutions and bureaucrats are motivated to act inefficiently. The responses one develops to these two forms of inefficiency are significantly different. ${ }^{89}$

One accepted rationale for government action holds that case 1 inefficiency may be relatively common - that is, we assume that government failure represented by inefficient choices may occur even when bureaucrats are motivated to maximize aggregate social welfare. The problem that generates this type of government inefficiency is related to an inability to identify and quantify the demand for goods that exhibit 'shared indivisability.' ${ }^{\circ}$ The government often does not have enough information about who will benefit or be injured as a result of state action, and similarly does not have information about the value those people place on the good or bad. As Mancur Olsen suggests, we do not have the analytical or experimental techniques to identify the production function of the public good, its optimal quantity, the value the public places on it, and the possible substitutes that would be offered by alternative suppliers (governments). ${ }^{9^{1}}$ The courts, and perhaps other institutions, since they must live with the same paucity-of-information characteristics of public goods, seem unlikely to be capable of more accurate decisions that would have to be made in order to impose liability in such cases. ${ }^{92}$

those it has made worse off (misfeasance) but should not be liable if it has simply failed (that is, if it is simply guilty of nonfeasance) to maximize benefits to all groups, which would be the Pareto-optimal decision. This is a false distinction, in that if both Pareto-optimal and various Pareto-superior schemes can be deduced, the government should choose the Pareto-optimal. To prefer a Pareto-superior scheme over a Pareto-optimal one is as much a positive choice act as any other.

89 Efficient state action is represented by choices and actions that maximize the aggregate social welfare, while all other choices - whether they maximize bureaucratic, political, or any other sub-category of welfare - are inefficient.

9o These goods are those which, like national defence, transportation infrastructures, and information about government programs, can be distributed on an individual basis in quantities an individual can purchase and enjoy privately. When markets and prices do not operate efficiently, it is difficult to identify and value public demand for the good.

$91 \mathrm{M}$. Olsen 'Official Liability and Its Less Legalistic Alternatives' (1978) 42 Law $\mathcal{E}^{2}$ Contemp. Prob. 67, at 73-5

92 It is also true that such a review process would raise profound questions about democratic government. An implicit assumption in such a proposal is that the political will equals a desire that the government promote its definition of the public good. A different assumption is that the political will equals a desire that the government promote what the 'public' believes is the public good. If the second assumption is true, then a review institution would have to assess not only efficiency considerations but also the public's satisfaction with having its policy preferences implemented even if the public later regrets the choice. Perhaps one value of the state is the learning process engendered by its continual mistakes. 
A second basis for assuming that even social welfare-maximizing bureaucrats may choose inefficiently is that bureaucrats may fail to take into account non-budgetary costs, or perhaps may discount non-budgetary costs more than they ought to. This phenomenon, referred to as 'fiscal illusion,' has been used to justify the adoption of liability rules that will transform social costs into budgetary costs in the case of expropriation and other state activities involving deliberate regulatory and distributive choices. ${ }^{93}$ Theories of public administration that treat bureaucracies as rational market participants suggest that planners will interpret data in such a manner as to maximize the probability that their departmental objectives will be achieved. ${ }^{94}$ More important, the socio-economic impact analysis currently employed in the federal bureaucracy does not include contingent risks of legal liability associated with state action as a regulatory risk. ${ }^{95}$ Moreover, bureaucracies may take into account and respond to a subset of costs imposed on highly organized groups of victims as well as to highly focused costs. ${ }^{96}$ Given the random impact of tort losses, the costs of litigation, and the omission of contingent liability risks from social cost-benefit analysis, fiscal illusion may be a common source of government failure. If that is true, then, at least in theory, liability rules coupled with internal administrative processes that respond to liability risks may be an effective signalling device where losses are associated with inefficient state actions of this sort. ${ }^{97}$

Several writers who have developed models of efficient compensation rules have assumed that state action is efficient, or at least that bureaucrats are motivated to act efficiently. ${ }^{8}$ There is considerable evidence, however, to support a different assumption - that 'deliberate' government failure is as common as its more familiar private market economic counterpart. ${ }^{99}$ It is frequently argued that elected politicians, government

93 See Kaplow, supra note 5,567 , and L. Blume and D.L. Rubinfeld 'Compensation for Takings: An Economic Analysis' (1984) $72 \mathrm{Col}$. $L R{ }_{5}^{69}$, at 580 .

94 See J. Hirshleifer 'Comment on Peltzman' (1976) 19 J. of Law E Econ. 241.

95 See Treasury Board of Canada Administrative Policy Manual Chapter 490 (Hull, PQ: Canadian Government Publishing Centre Dec. 1979) Appendix E (evaluation methodologies), and G.B. Doern Rationalizing the Regulatory Decision-Making Process: The Prospects for Reform Working Paper no. 2, Economic Council of Canada, Regulation Reference (Ottawa: Economic Council of Canada 1979) at 84-93.

96 As Blume and Rubinfeld point out, the presence of fiscal illusion is likely to be associated with certain types of state action. To the extent that the expected losses of a project are concentrated on an influential group of potential voters, we can expect less fiscal illusion (in terms of discounted costs) than in cases of highly dispersed losses: supra note 93,622 .

97 As I point out in part $\mathrm{v}$, however, more accurate and less costly signalling devices are available.

98 See, for example, Blume and Rubinfeld, supra note 93,580 .

99 This is the point that is frequently overlooked in Ronald Coase's now famous article on the ability of private market arrangements to internalize social costs: supra note 2 , $17-18,27-8$. 
bureaucrats, and bureaucracies are 'non-maximizing,' and are motivated instead by self-interest - including an interest in enhancing their personal wealth, professional stature and prestige, departmental size, power and budgets, and managerial discretion. ${ }^{100}$ There is a great deal of evidence to suggest that bureaucratic decisions are influenced by personal motives of departmental aggrandizement, especially in cases where the department has substantial independence from superior bureaucracies. ${ }^{101}$ If we assume that government, a particular government agency, a particular group of bureaucrats, or an individual bureaucrat is motivated to benefit herself through decisions that increase her personal welfare, and that her personal welfare is independent of the welfare of potential victims of her activities, then, in theory, liability rules ought to be imposed. ${ }^{102}$

Another set of arguments suggests that bureaucracies, like legislative institutions, are subject to majoritarian coercion and that this risk 'undermines any assumption that outcomes are necessarily welfaremaximizing., ${ }^{103}$ Thus, there is no reason to take as a starting-point the assertion that governments, like private economic actors, 'attempt to minimize overall costs. ${ }^{104}$ I find it difficult to accept that majoritarian influence is a single explanation for bureaucratic action; it may be that pluralist democrats would rephrase the problem as the non-social welfare-maximizing functions of coalitions of minorities. ${ }^{105}$ Whatever the details might be, in the context of tort claims one might posit that the majority of individuals who are not tort victims will exercise their abilities to influence the bureaucracy to maximize their private welfare at the expense of those who suffer losses as a result of state action. ${ }^{106}$ If that

100 See W.A. Niskanen Jr Bureaucracy and Representative Government (Chicago: Aldine 1971) at 48 , and J.-L. Migue and G. Belanger 'Towards a General Theory of Managerial Discretion' (1974) 17 Pub. Choice 27.

101 See M. Olson The Logic of Collective Action (Cambridge: Harvard University Press 1965), and A. Downs Inside Bureaucracy (Boston: Little, Brown 1967).

102 The same arguments apply in cases of government action that is motivated by a bureaucratic interest in maximizing the welfare of private interests. The only difference between the two is that in the latter the private welfare-maximizing agenda may have been approved by the electorate in some general sense, and thus is not so easily viewed with moral opprobrium. However, the critical variable - that government decisions will fail to take into account social costs - is present in both.

103 Quinn and Trebilcock, supra note 2, 173; M.J. Trebilcock, D. Hartle, J.R.S. Prichard, and D.N. Dewees 'The Choice of Governing Instrument: Some Applications' Economic Council of Canada, Technical Report No. 12 (Ottawa: Economic Council of Canada 1981) at Chap. I.

104 Spitzer, supra note $5,5^{15}$

105 See R.A. Dahl Who Governs (New Haven: Yale University Press 1961); R.A. Dahl, $A$ Preface to Economic Democracy (Berkeley: University of California Press 1985) at 46.

106 One might argue against this description of bureaucratic action, however. For example, if tort accidents are distributed randomly among the population, the majority will reflect the interests of potential tort victims, and thus, ex ante, will attempt to influence the bureaucracy to minimize their expected accident costs. 
assumption is true, then liability rules should be employed in those cases to shift losses to the government. ${ }^{107}$

We might also posit the existence of a set of bureaucrats who are characterized by abusive motives. ${ }^{108}$ In cases where judges have identified bureaucratic decisions motivated by private gain to inflict personal or economic injury on private citizens, they have imposed personal liability on the bureaucrat for the tort of intimidation or abuse of office. ${ }^{109}$ Similarly, legislative provisions affording tort immunity to bureaucrats commonly do not apply to actions taken in "bad faith." 10 These bureaucrats or bureaucracies, if they exist, ought to be subject to liability rules that force them to take into account the losses associated with their malevolent acts. ${ }^{11}$

This suggestion is subject to three caveats. First, it assumes that we can distinguish between malevolent bureaucrats and others at a cost that is less than the aggregate benefit associated with the loss internalization. Second, in so far as we permit insurance against merely inefficient bureaucratic actions, we must be able to deny insurance to bureaucrats in respect of malevolent decisions. This will generate administrative costs either ex ante or ex post, and we will have to pay for 'false positives' represented by the residual risks faced by individual bureaucrats who may be incorrectly labelled malevolent. Finally, if we do shift this loss to the state as an institution, the benefits associated with that loss-shifting must be closely evaluated. Rogue bureaucrats are difficult to identify ex ante, and it is difficult to think of institutional responses that will effectively reduce the risks to the public associated with their actions.

If one assumes inefficient state action in both case 1 and case 2 , it can be argued that liability rules are an appropriate regulatory tool. None the less, even under that assumption we would not necessarily choose to design liability rules based on models employed in the private sector. In assessing the desirability of liability rules we are concerned with their net marginal benefits, and we must take account of the response of the government to potential and actual liability risks, given that the government is not constrained by competitive capital or product markets.

107 This argument is subject to the analysis in part 4.

108 This is Spitzer's 'malevolent entity' supra note $5,534-6$.

109 See Roncarelli v. Duplessis, supra note 75, 143 (SCR); Takaro Properties Ltd v. Rowling [1976] 2 NZLR 657, at 662-4 (sC); Trobridge v. Hardy (1955) 94 CLR 147 (HC); and Gershman v. Manitoba Vegetable Producers' Marketing Board supra note 75 . It should be noted that in Gershman the board rather than the individual bureaucrat was identified as the malevolent entity.

110 See, for example, Trade Practice Act, RSBC 1979, c. 406, s. 16(1); The Summary Offences Procedure Act, Rss 1978, c. s-63, s. 7; and Liquor Control Act, RSA 1980, c. L-1 7 , s. 77(4).

111 It is implicit in this analysis that I do not view the welfare gains to the rogue bureaucrat as contributing to the aggregate welfare of society. 
Simply to say that government failure may be an explanation for non-optimal (inefficient) decisions does not necessarily lead to the conclusion that we should review state action by using liability rules. It is obvious that the only relevant benefits of liability rules are those net marginal benefits that would be generated in addition to the lossinternalization associated with existing or alternative legal, regulatory, and political instruments. That is, in assessing the desirability of imposing liability rules on government, we must be cognizant of the costs associated with the review mechanism, and of alternative regulatory instruments whose actual or potential existence reduces the benefits associated with implementing a government liability regime.

\section{THE COSTS OF LIABILITY RULES}

Even a cursory analysis of the review process associated with liability rules reveals how complex and intractable it will be. ${ }^{12}$ I argued earlier that if one is concerned with the internalization of social costs, liability rules are appropriate only in cases of inefficient state action. ${ }^{113}$ The evidence we have so far suggests that courts are aware of their limited institutional competence to determine whether state actions are allocatively efficient. The review would necessarily involve either replacing the politicalbureaucratic definition of the social welfare function, or evaluating whether the bureaucracy achieved the outcome that definition would have called for. In theory, direct state liability involves the review of legislative and senior executive decisions by the courts (assuming that curial institutions are retained in the review process). Not surprisingly, judges have traditionally denied their authority to review the legislative and senior executive institutions of the state, ${ }^{114}$ and the federal legislation

112 For example, there has been considerable debate in the United States about the appropriate role of the courts in evaluating cost-benefit analyses carried out by administrative agencies. Judge David Bazelon suggests that the courts defer to administrative expertise in reviewing agency cost-benefit analyses. See D. Bazelon 'Coping with Technology through the Legal Process,' cited in M.S. Baram 'Cost-Benefit Analysis: An Inadequate Basis for Health, Safety, and Environmental Regulatory Decision Making' (1980) 8 Ecology $L Q 473$, at 476 . Compare $H$. Leventhal 'Environmental Decision-Making and the Role of the Courts' (1974) 122 U. Pa. LR 509, at 555 .

113 'Inefficient state action' refers to the activities of public bureaucrats that fail advertently or inadvertently, to take into account their full social costs. This definition ignores the redistributive role of most modern governments.

114 In the case of provincial and federal governments the issue has arisen in the review of Crown prerogatives, and in attempts by victims of state action to argue that the cabinet or particular ministers are Crown servants for the purposes of vicarious liability under the relevant Crown liability legislation. These cases are not precisely on point, since in the first executive action is reviewed, while in the second individual conduct is reviewed and the imposition of vicarious liability on the state is urged. None the less, they are 
providing for tort liability in limited circumstances specifically excludes liability for losses associated with the exercise of executive prerogatives. ${ }^{115}$

Even if we could restrain the review institution from applying its own definition of the social welfare-maximizing choices, it would still have to determine the potential outcome of the bureaucratic welfare-maximizing choice, compare it with the actual outcome (keeping all other variables constant), and award damages representing the difference. Leaving aside the administrative costs of identifying the 'victims' and distributing the damage award, the determination of the two critical elements of the equation - the outcome of the potentially Pareto-optimal choice, and the outcome of the choice that was made - would generate enormous costs, and would be characterized by substantial error costs in the current or any imaginable review process.

The review process would not be significantly simplified, nor would its accuracy be improved, if we were to relax the requirement of potential Pareto-optimality and simply demand that governments motivated to act efficiently pay damages when their decisions were not potentially Pareto-superior. One might assume, for the sake of argument, that governments motivated to act efficiently should act only after engaging in a social cost-benefit analysis of the proposed choice, and that action is taken only when the expected benefits of the action exceed its expected costs. ${ }^{116}$ If a person were less well off as a result of government action

close approximations of the review process we could expect if a direct liability regime were established in these jurisdictions.

In the case of Crown prerogatives, the courts have refused to engage in substantive review except on constitutional grounds. See S.A. De Smith Constitutional and Administrative Law $4^{\text {th }}$ ed. (Harmondsworth: Penguin 1981) at 137, and Attorney General v. Nissan [1 1970] AC 179 .

In the case of ministers, the courts have said that ministers are not officers or servants of the Crown. See McArthur v. R. [1934-4] Ex. CR 77, Belleau v. Minister of National Health and Welfare [1948] Ex. CR 288, [1948] 2 DLR 632, and Mavor v. The King (1919) 19 Ex. CR 304, 51 DLR 145.

115 See Crown Liability Act, RSc 1970 , c. c- 38 , s. $3(6)$. I do not know if there is an easy answer to the problem, but it does not seem possible to design an 'efficiency review institution,' keeping in mind that allocative efficiency will incorporate distributive choices. What might be possible is the application of enterprise liability to the state by a non-judicial review institution, which will overcome the concerns about separation of powers and institutional competence that generate judicial reticence when judges are asked to review the decisions of cabinet and other senior bureaucracies. For reasons I give later, I do not believe that even this proposal is justified.

116 While many would argue that the regulatory state ought to be governed by that directive, it is both naïve and optimistic to think that government policy is a product of that exercise. None the less, in December 1979 the federal Treasury Board announced a new policy governing all major new regulations or amendments of existing regulations relating to health, safety, or fairness. Under chapter 490 of the Administrative Policy Manual, all such regulations must be subjected to a socio-economic impact analysis. The risk or cost aspect of the analysis represents an attempt to ascertain the resources used in producing government benefits. The government department is 
taken after the impact analysis, it would be possible, in theory, to review the analysis to determine whether it was carried out correctly. If the reviewing institution determined that the state action should not have been carried out in view of its assessment of the expected costs and benefits of the choice that was made, compensation would be paid to the victim. The difficulty with this model of tort law is that the review of the social cost-benefit analyses carried out by the government is dramatically different from the review of analogous decisions in the private sector. ${ }^{117}$

For example, many current models of social cost-benefit analysis expressly mandate an assessment of the impact of a proposed regulation on such variable as income distribution and regional balance, technological progress, market structure and competition, balance of payments, international competitiveness, energy consumption, and inflation. ${ }^{118}$ To the extent that these factors are integrated into the decision-making process, it is impossible to review them unless we are willing to accept the reviewing institution as a super-government. Further, it is of ten necessary to value human lives and suffering, and the distributional consequences of state action, in determining the desirability of government activity. The arguments about the appropriate figures to use in such cases, and indeed the appropriate methodology to be used, do not seem to me to be capable of resolution in a review forum. Moreover, the costs associated with redoing the social cost-benefit analysis using non-experts would be

likely to be aware of its accounting budget, involving direct government expenditures on administration, implementation, and policing. The assessment of government action must involve a determination of the economic budget associated with a particular policy, which will encompass all private and public costs. See A. Breton and R. Wintrobe The Logic of Bureaucratic Conduct (Cambridge: Cambridge University Press 1982) 20-2.

117 I should point out that implicit in this argument is an assumption that the use of a common law tort negligence standard to review government liability is inappropriate. It is obvious that efficiency has a larger scope that negligence, which, as conventionally defined, does not look to all the factors that collectively determine efficiency.

A second point implicit in my argument is whether the government should be made to adhere to a negligence standard, or to an economic efficiency standard if those two ideas are not coincident. For example, should the government be liable if it ignores accepted economic expertise in reaching its decision - that is, when it chooses to ignore the easily predictable effects of an admittedly political decision? Or should it be liable only for damages caused through the negligent administration of a policy? The electorate itself may be said to be acting negligently with regard to economic information. Should the government be allowed to act inefficiently, and knowingly so, when possessed of the broad support of the electorate? Here I think the answer must be yes. If not, democracy would be reduced to the rubber-stamping of policies endorsed by the economically reasonable man. We must recognize the importance of separating policy decisions (and the inefficiencies they impose on administrative decision-making) from inefficient administrative decisions for which the state should be held liable when the decisions are made independent of a policy decision.

118 See Treasury Board Canada, Administrative Policy Manual, supra note 95, chapter 49o, at section 3.1.2 and Appendix E at 14-18. See also F. Thompson and L.R. Jones Regulatory Policy and Practices (New York: Praeger 1982) 152-74. 
substantial. Even identifying the resources expended in the private sector in response to the public activity, and valuing those resources (a necessary element in a socio-economic impact analysis) would generate significant costs. $^{119}$

The review process, even when it is applied to less formal instances of government decision-making, is no simpler to design and implement. For instance, one might imagine a decision of the police to dispense with special protection for a young woman who notifies them of a suspected assault by a spurned boy-friend. Carried out properly, this choice would involve trade-offs between the marginal cost of overtime pay for extra police protection in view of the expected benefits of providing the service, and existing demands on the allocation of limited police resources to crime detection, traffic control, public education, and other requests for special protection. ${ }^{120}$ Unless we can value the demand for these goods, ascertain the costs of supplying them, and determine whether we should have substituted the complainant's good for the good that was produced, we cannot determine whether the decision was inefficient or efficient. Thus, if one assumes that the government is motivated to maximize social welfare, it does not seem feasible to establish a comprehensive review process that could effectively review the decisions of the government to determine whether the choices generated efficient outcomes. ${ }^{121}$

119 This, of course, is the explanation for the development of doctrinal rules that attempt to distinguish 'policy-making' and the choice of government objectives from 'implementation' and execution of the policy. One of the first indications that the courts would immunize the former from judicial review in compensation claims was Anns $\mathrm{v}$. Merton London Borough Council [1978] AC 728. I have criticized the development of this 'discretionary' exemption, as it is sometimes called, not only for its indeterminacy but also for its naïvety in assuming a hierarchical structure and a formal discontinuity between stages in the design and production of regulatory goods. See D. Cohen 'The Public and Private Law Dimensions of the UfFi Problem' $(1983-4) 8$ Can. Bus. LJ 410. In recent decisions courts in Australia and England have rejected this aspect of $A n n s$ and replaced it with an equally abstruse concept. See, for example, Governors of the Peabody Donation Fund v. Sir Lindsay Parkinson and Co. Ltd [1985] 1 AC 210.

120 See Riss v. City of New York 240 NE $2 \mathrm{~d} 860$ (1968), and Bass v. City of New York 330 NYS $2 \mathrm{~d}$ 569 (1972), aff'd 300 NE $2 d 154$ (1973) (no liability on housing authority for failure adequately to protect physical safety of young girl assaulted on authority property). See also K.C. Davis Discretionary Justice (Baton Rouge: Loujsiana State University Press 1969) 8o-8, $162-9$.

121 One possible solution to the problem of determining whether government action is efficient would be to adopt a strict liability rule in which the only relevant criterion for compensation would be a demonstration of a sufficient causal relationship between government action (or inaction) and the claimants' losses. I do not mean to underestimate the difficulties associated with reaching conclusions about causal relations. And no one can possibly believe that mono-causality is operating in the case of state wrongs.

None the less, strict liability would reduce, though it would not avoid, the administrative costs of determining inefficient state action, and would shift the efficiency determination to the state. Under certain assumptions (which might not hold true in a significant number of cases), the state would respond by adopting efficient 
THE MARGINAL BENEFITS OF LIABILITY RULES

In the case of private torts, liability rules operate and should be evaluated in the context of the market as a regulatory tool. If the market is working perfectly, ${ }^{122}$ tort law is unnecessary if all one cares about is primary accident-cost avoidance. Similarly, in the case of public torts, liability rules operate in the context of the political market as a regulatory tool. The political market, however, is not examined and evaluated easily, and it may not operate in the same fashion across the bureaucracy. ${ }^{123}$

Yet the political market in its various guises may justify state and bureaucratic immunity if it is operating effectively as a cost-internalization mechanism. For example, it has been argued that it is unnecessary to impose liability on some bureaucrats since they are subject to parliamentary accountability. ${ }^{124}$ It has also been suggested that it is unnecessary to provide damage actions against some elected officials in view of their regulation by electoral markets. ${ }^{125}$ Although there have been isolated instances of legislative compensation in the case of mass tort victimization $^{126}$ and banking failures, ${ }^{127}$ the transaction costs of legislative action suggest that it is a highly imperfect alternative to liability rules. Whether parliamentary review takes place ex ante through ongoing reporting and

accident-reduction measures and shifting residual costs to its constituents. While this might be attractive in some instances of state action, the proposal implicitly assumes that the state is not taking those losses into account ex ante. Thus it solves the problem, but only after rejecting the assumption that led to the problem in the first place.

There may be persuasive reasons to implement 'no-fault' loss-compensation programs in respect of certain state activities. See Schuck, supra note $57,112-13$. But if one assumes that the government is taking into account social costs, strict liability would not be the optimal liability rule.

122 That is, where there are no transaction or enforcement costs, all losses, victims, and injurers are identifiable immediately and at no cost, and all losses are shifted immediately and at no cost.

123 Perhaps the most significant aspect of at least some aspects of the political market is that it operates in secret, making it next to impossible to evaluate its effectiveness. As well, some bureaucracies, including the judiciary and prosecutorial officers, are valuable precisley because of their relative independence from direct political influence.

124 A dramatic example of this argument was Justice Powell's suggestion that the possibility of impeachment was evidence of the historical immunity of President Nixon. See Fitzgerald v. Nixon supra note 66, $270_{5}$. See also W. Gourlie 'Role of the Prosecutor: Fair Minister of Justice with Firm Convictions' (1982) 16 UBCLR 395, at 300.

125 See Fitzgerald v. Nixon supra note 66, 2705-6.

126 Possibly the most famous example of legislative review giving rise to compensation is In re Texas City Disaster Litigation (a District Court awarded judgment to plaintiffs; a Court of Appeal reversed, 197 F. $2 \mathrm{~d} 771$; affirmed sub no. Dalehite v. United States 346 u.s. 15 (1953)), where Congress awarded up to $\$ 25$, ooo per claimant for losses arising out of the explosion of fertilizer with an ammonium nitrate base at Texas City, Texas, in April 1947. See Texas City, Texas Disaster Claims, PL 378, stat. 707 (1955). The American Supreme Court had denied compensation under the Federal Tort Claims Act, 28 usc, ss. 1346, 2671-8, and 268o. See also A.W. Reitze 'Federal Compensation for Vaccination Induced Injuries' (1986) 13 Boston Coll. Env. Aff. LR 169.

127 Financial Intitution Depositors Compensation Act, sc 1986 , introduced in the House of Commons on 7 October $19^{8} 5$ 
budgetary review, or ex post through reporting in the Public Accounts, it is fair to say that political review of discretionary powers is weaker than review of other aspects of administrative behaviour. ${ }^{128}$ In the light of the random impact of tort victimization and in the absence of an organized political focus for tort victims, that intuition seems to be justified. Again empirical data are unavailable to support this assessment. ${ }^{129}$

A second potential regulatory instrument is judicial review in its traditional administrative guise. But again, most investigators of the administrative process have concluded that judicial review is not an effective regulatory tool. ${ }^{13^{\circ}}$ Even if it were, judicial review resulting in bureaucratic decisions being declared unenforceable does not result in loss-shifting. ${ }^{131}$

A third 'political' accountability mechanism may be professional norms of conduct - the values and attitudes that are internalized as part of bureaucratic training and experience. ${ }^{13^{2}}$ It may be true that this is the most powerful control mechanism; it has the additional benefit of being self-enforcing. Where the bureaucratic process is characterized by professional norms, the necessity of judicial regulation through tort law is questionable, since behaviour is shaped and modified by internalized norms of conduct. The internal regulatory methods by which subordinates are controlled by superiors take the form of formal rules that support the professional norms; they represent hierarchical control within

128 F. Slatter Parliament and Administrative Agencies working paper (Ottawa: Law Reform Commission of Canada 1982) 38-41, 114

129 It should be noted that critics of parliamentary accountability accept its theoretical possibility but argue that as a practical matter street-level bureaucrats operate in a manner which necessarily means that they are unconstrained by legislative review. See Law Society of Upper Canada Report on the Abuse of Power and the Role of an Independent Judicial System in its Regulation and Control (Toronto: De Boo 1979) at 611.

130 This is especially so in the case of those bureaucrats whose decision-making has been declared unreviewable by the courts. Again, prosecutorial discretion comes within this class. See Gouriet v. Union of Post Office Workers [1978] AC 435; Nelles v. Ontario, supra note 66. Moreover, cases such as $R$. v. Rourke (1977) 38 CRNS 268,35 CCC (2d) 129 (sCC) suggest that Canadian judges are reluctant to review certain bureaucratic decisions except in the most egregious circumstances. It is true that since Rourke Canadian judges have engaged in judicial review of prosecutorial decisions, but notwithstanding John Edwards' confidence that this is an effective regulatory tool, it seems that judges are still hesitant to impose sanctions on bureaucrats, at least in this context. See J.LI.J. Edwards The Attorney General, Politics and the Public Interest (London: Sweet and Maxwell 1984) at 120.

131 See Bosada v. Pinos (1984) 5 DLR (4th) 334 , at $33^{8}$ (Ont. HC).

132 This point has been made by both supporters and critics of bureaucratic immunity. See K. Turner 'The Role of Crown Counsel in Canadian Prosecutions' (1962) 4o Can. Bar Rev. 439; Boucher v. The Queen (1954) $110 \mathrm{CCC} 26_{3}$, at 270 (scc), per Rand J, who described the public duty of Crown prosecutors. One can compare these remarks with those of Mark Tushnet in 'The Constitution of the Bureaucratic State' (1984) $86 W$. Va. LR 1077 . 
the agency through rules and norms and an alternative to control by external agencies. ${ }^{133}$ Paradigmatic cases include public prosecutorial decision-making, judging, and law enforcement investigation. In these cases bureaucratic incentives are professional rather than economic, and the norms that establish and define what prosecutors, police, and judges ought to do are internalized through training and institutional constraints. If this is so, then damage awards against the state are unlikely to influence bureaucratic behaviour.

Yet professional norms might not coincide with efficient loss-reducing decisions. For example, in the case of 'prosecutor-bureaucrats' a relevant norm might be the win-loss ratio of the individual prosecutor. ${ }^{134}$ There is no reason to believe that this necessarily coincides or is even directly related to a socially optimal decision criterion, and there is the risk that prosecutorial decisions constrained by professional norms of conduct will lead to decisions to prosecute individuals whom the bureaucrat thinks she will be able to convict, rather than individuals 'ought' to be prosecuted. ${ }^{135}$

Even this cursory review of the current 'political' markets that might be operating to internalize social costs suggests that they do not work 'perfectly.' None the less, to the extent that they do, we focus on the marginal benefits associated with state liability, and should hesitate to impose liability without a thorough analysis of the costs and benefits of existing and alternative accountability mechanisms.

\section{Responses of the state to liability rules}

In part I I described the arguments against the imposition of personal bureaucratic liability, and suggested tentatively that direct state liability might be the preferred regulatory instrument when the objective is to reduce the incidence and consequences of state-caused losses. In part II I argued that such a proposal is attractive only when one assumes

133 Tushnet, supra, $1095-6$. The bureaucratic process is neither utilitarian nor contractarian, but is characterized by 'decisions [made] in light of profesisonal norms.'

134 See B.A. Grossman 'Conflict and Compromise in the Criminal Courts: New Directions in Legal Research' (1968) 1 i Crim. LQ 292, at 294.

135 R.H. Jackson makes this point in 'The Federal Prosecutor' (1940) 24 J. of Adm. Jud. Soc. 18 , at 19. It is true that nothing is wrong per se with decisions to prosecute that are based on the probability of convictions. None the less, other variables, including the likelihood of future criminal activity and the attitude of the public to the crime and to convictions, are ignored in the calculus.

The problem is one of conflicting incentives. The prosecutor may react to internal departmental budgetary and administrative signals that demand productivity, and not to the invisible signals from the victims of those decisions - persons who ought not to have been prosecuted in view of the social benefits associated with their incarceration,

- and persons who are victims of criminals who ought to have been prosecuted. 
inefficient state action. In part III I argued that even in cases of inefficient state action, liability rules may be undesirable in view of their costs and the existing legal regulatory instruments. ${ }^{136}$ Here I argue that even in the case of inefficient state action, liability rules may be undesirable given the ability of the state to 'externalize' losses across taxpayers.

Richard Posner is the strongest proponent of the application of tort law to state action; he recommends the use of liability rules to regulate government action in a number of contexts. ${ }^{137}$ Posner suggests that traditional doctrines intended to influence bureaucratic behaviour in the context of law enforcement activities - including the entrapment defence and the exclusionary rule - are themselves inefficient, and ought to be replaced by tort damage actions against the government. ${ }^{13^{8}} \mathrm{It}$ is not easy to dismiss the claim that non-monetary remedies are inefficient. Such remedies generate the dead-weight losses associated with the imposition of sanctions which reduce social welfare without an associated gain in deterrence, ${ }^{139}$ and which may over-deter the regulated conduct. ${ }^{14^{\circ}}$

None the less, the critical assumption behind such recommendations is that the government reacts to liability rules as a private economic actor would. In contrast, a 'no liability' rule is optimal ${ }^{14}{ }^{1}$ when one assumes that the government and bureaucratic agencies will not react to economic incentives. That is, only if one assumes that the state, like a private firm, is constrained by relatively efficient markets in labour, products and capital can one predict that the state will react to liability risks by adopting efficient accident-reduction measures. ${ }^{14^{2}}$

136 Of course, all of this assumes that the only relevant state objective is to engage in the efficient delivery of regulatory benefits. We can certainly justify liability rules when we want to achieve other objectives - recognizing and protecting 'rights,' providing for loss-spreading engaging in public insurance programs, and so on.

137 See Posner 'Rethinking the Fourth Amendment' supra note 59 and Posner 'Excessive Sanctions' ibid. 635-6, and C. Foote 'Tort Remedies for Police Violations of Individual Rights' (1955) 39 Minn. LR 493 .

138 Although Posner recognizes the problems associated with personal bureacratic liability, his suggestion of government liability on the basis of respondeat superior doctrines without rights of indemnification assumes that the threat of liability would give the agency 'an incentive to prevent misconduct by its officers': 'Excessive Sanctions' supra note 59,641 .

139 G.S. Becker 'Crime and Punishment: An Economic Approach' (1968) $76 \mathrm{~J}$. of Pol. Econ. 169; R.A. Posner 'Optimal Sentences for White-Collar Criminals' (1980) $17 \mathrm{Am}$. Crim. $L R 409$, at 410.

140 The inefficiency of over-deterrence is represented by the opportunity costs of the regulatory benefits that are not produced as a result of bureaucratic inaction: Posner 'Excessive Sanctions' supra note 59,637. See also United States v. United States Gypsum Co. $43^{8}$ U.S. 422 , at $440-3(1978)$.

141 See Posner, 'Rethinking the Fourth Amendment' supra note 59, 66.

142 See D.N. Dewees 'Regulating Environmental Quality' in D.N. Dewees (ed.) The Regulation of Quality: Products, Services, Workplaces, and the Environment (Toronto: Butterworths 1983) 153; W.J. Baumol and W.E. Oates Economics, Environmental Policy, 
THE IMPACT OF DAMAGE CLAIMS AGAINST THE STATE

In theory, internal accident-reduction measures are a likely response to liability rules applied by an exogenous review institution. ${ }^{143}$ Risk management would involve superior agencies' assuming responsibility for detecting, identifying, and controlling the risk-increasing activities in which its subordinate departments and employees engage. Accident costs would be minimized to the extent that efficient risk-management measures could be designed and implemented, and insurance arrangements would be implemented to spread losses over time and large numbers of insured parties. ${ }^{144}$ Moreover, because judges would not directly regulate agency policy or implementation, there would be a reduced risk that the judiciary would find itself running government programs. ${ }^{145}$

Government responses to accident risks would conceivably include an internal system of administrative discipline ${ }^{146}$ and the adoption of decision-making structures sensitive to the expected accident costs of state action. ${ }^{147}$ Governments faced with liability risks could be expected to

and the Quality of Life (Englewood Cliffs, NJ: Prentice-Hall 1979); and A. Alchian and H. Demsetz 'Production, Information Costs, and Economic Organization' (1972) 62 Am. Econ. Rev. 77.

143 At the very least one would avoid the administrative costs associated with teaching judges how they might reform the bureaucratic process to minimize the expected costs of government action, and it is a fair assumption that the senior bureaucrats will get it right more often than judges, even after that educative process.

There seems to be very little empirical data describing the response of bureaucracies to liabilty risks. A review of Canadian Public Policy up to 1985 , Canadian Public Administration to the spring of 1986 , the Journal of Political Economy from 1965 to 1985 , and the Journal of Public Economics from 1965 to 1985 uncovered no relevant material. Two articles on municipal risk management were anecdotal rather than theoretical or empirical: see R. Breber 'Are Risk Managers Needed in Cities?' (1985) 67 Public Management 7, and 'Risk Management' (1978) 6o Public Management.

A special issue of Public Administration Review was devoted to government liability, but the articles on tort losses were not particularly useful. See (2985) 45 Public Administration Review $74^{2}$.

144 It would be highly unusual for central governments to obtain market insurance in respect of regulatory risks; the ability of the insurer to predict and evaluate the risks, and to pool and spread the losses, probably would be inferior to the insured's. However, governments whose tax base and authority are constrained may very well obtain market insurance in respect of 'non-governmental' risks. See, for example, Risk Retention Act, 15 USC, ss. 3901 et seq., as amended. Congressional amendments in 1986 provided in s. 3901 (a)(2)(A)(ii) for the extension of risk-retention benefits to all state and local government activities.

145 As Peter Schuck notes, it is unlikely that courts, or indeed any institution that designs and implements tort remedies, could be sensitive to the demands of the immense range of functions in which the government is engaged, design effective deterrent mechanisms suited to those contexts, and implement and monitor them at the street level: supra note 57,103 .

146 See Bermann, supra note 24, 1202.

147 Michael Trebilcock and Douglas Hartle develop this idea in the context of regulatory costs in 'Regulatory Reform and the Political Process' (1982) 20 Osgoode Hall LJ 643. 
implement risk management measures to monitor and identify potential exposure and to reduce the probability and magnitude of expected losses through internal management decisions. ${ }^{14^{8}}$ These responses might involve improved training and employee selection programs, and the adoption of remuneration practices linking accident costs to salaries and promotions. ${ }^{149}$

However, analyses of damage claims against the federal government over recent years and of the budgetary and payment mechanisms within the federal government suggest that the state cannot be assimilated to the position of a private firm. The current internal administrative systems operating at the federal level of government supports the view that the response of the government to legal liability risks will not generate a reduction in accident costs. The incentive effect of potential or actual legal liability on a particular department should depend, to a considerable

148 Current risk management procedures in use in federal bureaucracies are described in chapters $320,530,531$, and 532 of the Treasury Board Manual. In chapter 320 (entitled 'Risk Management') government departments are directed to record information relating to the number, type, and dollar value of harmful or damaging occurrences; the annual number of claims by type and location; security infractions by type and location; and the annual dollar value of any insurance purchases. Risks to government assets and risks to government personnel are dealt with in chapter 530 ("Management of Risk Generally'). In identifying risks, departments are directed to assess damaging agents, including human and physical factors, and to distinguish between risks peculiar to government and general risks. Departments are then directed to engage in riskminimization efforts, including risk avoidance, options designed to minimize the financial consequences of accidents, and special employment practices, including safety, prevention, and training. Chapter 530 also provides directions on loss containment and the avoidance of fire risks through compliance with standards. Chapter 531 ("Management of Risk - Underwriting') describes government insurance practices. Fire and automobile risks are self-insured. Exceptions to this self-insurance presumption include cars at foreign posts and steam boilers. The government does not maintain a fund dedicated to underwriting risks, and funding is generally the direct responsibility of the individual department which generates the accident. There is interim financing available to a department if extreme financial difficulty arises, but advances received are expected to be repaid through supplementary or future appropriations. Chapter 532 (“Management of Risk Compensation/Restoration') describes claims investigation procedures. Restoration and compensation for intradepartmental incidents are delegated to the department. When a major incident occurs between departments, the Treasury Board considers departmental submissions, and when disputes arise it obtains opinions from the Department of Justice. Claims regulations are followed for tort claims, with the exception of defalcation by public officials.

149 See M.J. Jaron 'The Threat of Personal Liability under the Federal Civil Rights Act: Does It Interfere with the Performance of State and Local Government?' (1981) 13 Urb. Lauryer 1, at 21-2. F. Heffron and N. McFeeley The Administrative Regulatory Process (New York: Longman 1983) at 331; Newman 'Suing the Lawbreakers: Proposals to Strengthen the Section 1983 Damage Remedy for Law Enforcers' Misconduct' (1978) 87 Yale LJ 447, at 457; and P.C. Weiler 'The Control of Police Arrest Practices: Reflections of a Tort Lawyer' in A. Linden (ed.) Studies in Canadian Tort Law (Toronto: Butterworths 1968 ) at $445^{-6 .}$ 
degree, on the proportional impact of the costs of legal liability on the department's operating budget. Actual legal exposure (not including the costs of legal work) never exceeds 0.2 per cent $(1 / 500)$ of a departmental budget. ${ }^{15^{\circ}}$ (See the accompanying table.)

Furthermore, in departments where liability approaches that percentage, most of the liability costs represent property and automobile damage claims. ${ }^{15^{1}}$ There is no reason to believe that government employees drive more negligently than employees of private firms, and it does not appear that the costs of accidents are a result of government inefficiency. ${ }^{15^{2}}$ For several departments with relatively large legal costs, this type of liability (damage claims for vehicle accidents) is one in which the incentive effect of financial costs on accidents is notoriously difficult to determine, and is indeed the object of much scepticism. ${ }^{153}$ Thus, it seems reasonable for the department to view these costs as an operating cost and not to treat them as a tort liability amenable to risk-management procedures peculiar to government.

In any case, the data suggest that legal liability costs are probably not of major concern to any particular department in determining its budgetary estimates. Those estimates are never resolved within 1 per cent at the start of the fiscal year. ${ }^{154}$ Further, the cost of legal liability as a category of expenditure is never distinctly considered, ${ }^{155}$ but is assumed in current departmental budgets as a component of general operating costs. It is

150 The table was compiled from Receiver General for Canada Public Accounts of Canada, $1983-1984$ and Public Accounts of Canada, 1984-1985 (Ottawa: Ministry of Supply and Services 1984,1985 ). Details of damage claims, ex gratia payments, and Federal Court awards are in section 33 of vol. 2 of both years. Annual budgetary appropriations (non-statutory) are listed by department in table 2 of the introduction to vol. 2 of both years.

${ }_{15} 1$ In the case of the Departments of National Defence and Transport, automobile accidents predominate. Property damage and automobile accidents represent the vast majority of claims involving the RCMP in the Department of the Solicitor General.

$15^{2}$ A comparison of the number of accidents per miles driven between private firms and the government would be required to demonstrate inefficiency. Since the government is a self-insurer, there is no independent assessment of accident claims by which to assess premium rates.

153 See M.A. Franklin 'Replacing the Negligence Lottery: Compensation and Selective Reimbursement' (1967) 53 Va. LR 774 .

154 D.G. Hartle The Expenditure Budget Process in the Government of Canada (Toronto: Canadian Tax Foundation 1978) 40; Public Accounts supra note 150, vol. 1, section 4, table 4.3, 'Estimates and Appropriations' of both years. Several supplementary estimates are commonly made through the course of the year.

155 Telephone conversation 11 July 1986 with Allan Darling of the Programme Branch of Treasury Board. Mr Darling also stated that there had been no recent demands for funds for legal purposes in supplementary estimates. A further telephone conversation on 15 July 1986 with L. Endemann, Treasury Board officer for the Department of Justice, confirmed that to his knowledge funds for legal liability are never found in the main estimates. 
$1983-4$

\begin{tabular}{|c|c|c|c|c|c|c|c|}
\hline & $\begin{array}{l}1 \\
\text { Damage } \\
\text { claims } \\
\text { (in thousands) }\end{array}$ & $\begin{array}{l}\mathbf{2} \\
\text { Damage } \\
\text { claims } \\
\text { (motor vehicle } \\
\text { accident) } \\
\text { (percentage) }\end{array}$ & $\begin{array}{l}3 \\
\text { Ex gratia } \\
\text { payments } \\
\text { (in thousands) }\end{array}$ & $\begin{array}{l}4 \\
\text { Federal } \\
\text { Court } \\
\text { awards } \\
\text { (in thousands) }\end{array}$ & $\begin{array}{l}5 \\
\text { Total } \\
\text { payments } \\
1+3+4 \\
\text { (in thousands) }\end{array}$ & $\begin{array}{l}6 \\
\text { Total annual } \\
\text { budgetary } \\
\text { appropriation, } \\
\text { non-statutory } \\
\text { (in millions) }\end{array}$ & $\begin{array}{l}7 \\
\text { Payments } \\
\text { as a percentage } \\
\text { of annual } \\
\text { non-statutory } \\
\text { appropriation }\end{array}$ \\
\hline Agriculture & 55 & $3^{8}$ & 11 & & 66 & 1071 & .0062 \\
\hline Communications & 18 & 47 & $<_{1}$ & & 18 & $145^{1}$ & .0012 \\
\hline Consumer \& Corp. Affairs & 14 & $5^{6}$ & $<1$ & & 15 & 266 & $.005^{6}$ \\
\hline Employment \& Immigration & 36 & 0 & 3 & $3^{1}$ & 68 & 2130 & .0032 \\
\hline Energy, Mines, Resources & 7 & 0 & 1 & & 8 & $316_{5}$ & .00025 \\
\hline Environment & 100 & 65 & 291 & & $39^{1}$ & 877 & .045 \\
\hline External Affairs & 2 & 0 & 28 & & 30 & 1954 & .0015 \\
\hline Finance & $<1$ & 0 & $<1$ & & $<1$ & 96 & $<.001$ \\
\hline Fisheries \& Oceans & 81 & 70 & 63 & 116 & 261 & 626 & .042 \\
\hline Indian \& Northern Dev. & $5^{8}$ & 83 & 13 & 64 & 134 & 2061 & .0065 \\
\hline Nat. Defence & 2759 & 13 & 16 & 517 & 3309 & $733^{2}$ & .045 \\
\hline Nat. Health, Welfare & 19 & 53 & 30 & & 49 & 944 & $.005^{2}$ \\
\hline Nat. Revenue & 24 & 35 & 3 & & 28 & 900 & .0031 \\
\hline Public Works & 88 & 38 & 250 & 175 & 513 & 2840 & .018 \\
\hline Regional Ind. Exp. & 2 & 100 & $<1$ & & 2 & $15^{6} 5$ & .00013 \\
\hline Science \& Technology & 11 & 49 & 4 & & 15 & 709 & .0021 \\
\hline Secretary of State & & 0 & $<1$ & 5 & 9 & 616 & .0015 \\
\hline Solicitor General & $15^{87}$ & 62 & $3^{2}$ & $5^{1}$ & 1670 & $13^{86}$ & .12 \\
\hline Supply \& Services & 11 & 28 & 6 & 679 & 696 & 381 & .18 \\
\hline Transport & ${ }^{1} 59^{\circ}$ & 2.9 & 240 & & 1830 & 2960 & .062 \\
\hline Treasury Board & & & 17 & & 17 & 594 & .0029 \\
\hline Veterans' Affairs & $<1$ & & 11 & & 11 & 1426 & .00077 \\
\hline $\begin{array}{l}\text { Totals and weighted } \\
\text { averages }\end{array}$ & 6468 & $25 \cdot 5$ & 1020 & $173^{2}$ & 9220 & $3535^{\circ}$ & .026 \\
\hline
\end{tabular}


$1984-5$

\begin{tabular}{|c|c|c|c|c|c|c|c|}
\hline & $\begin{array}{l}8 \\
\text { Damage } \\
\text { claims } \\
\text { (in thousands) }\end{array}$ & $\begin{array}{l}9 \\
\text { Damage } \\
\text { claims } \\
\text { (motor vehicle } \\
\text { accident) } \\
\text { (percentage) }\end{array}$ & $\begin{array}{l}10 \\
\text { Ex gratia } \\
\text { payments } \\
\text { (in thousands) }\end{array}$ & $\begin{array}{l}11 \\
\text { Federal } \\
\text { Court } \\
\text { awards } \\
\text { (in thousands) }\end{array}$ & $\begin{array}{l}12 \\
\text { Total } \\
\text { payments } \\
8+10+11 \\
\text { (in thousands) }\end{array}$ & $\begin{array}{l}13 \\
\text { Total annual } \\
\text { budgetary } \\
\text { appropriation, } \\
\text { non-statutory } \\
\text { (in millions) }\end{array}$ & $\begin{array}{l}14 \\
\text { Payments } \\
\text { as a percentage } \\
\text { of annual } \\
\text { non-statutory } \\
\text { appropriation }\end{array}$ \\
\hline Agriculture & 22 & 35 & 89 & & 111 & 1405 & .0079 \\
\hline Communications & $3^{8}$ & 21 & 3 & & $4^{1}$ & .1537 & .0079 \\
\hline Consumer \& Corp. Affairs & 14 & $5^{2}$ & 1 & & 15 & $24^{8}$ & .0060 \\
\hline Employment \& Immigration & 15 & 23 & 3 & & 18 & 2259 & .00080 \\
\hline Energy, Mines, Resources & 2 & $\mathbf{0}$ & 75 & & 77 & 4213 & .0018 \\
\hline Environment & 143 & 74 & 1 & 61 & 205 & 799 & .026 \\
\hline External Affairs & $<1$ & o & $<_{1}$ & & 1 & 2187 & .000046 \\
\hline Finance & & $\mathbf{o}$ & 75 & 1319 & 75 & 103 & .073 \\
\hline Fisheries \& Oceans & 194 & 70 & 3 & & 1516 & 754 & .20 \\
\hline Indian \& Northern Dev. & $3^{2}$ & 72 & $3^{8}$ & & $7^{\circ}$ & 2202 & .0032 \\
\hline Nat. Defence & 2626 & 24 & 44 & & 2670 & 8237 & .032 \\
\hline Nat. Health, Welfare & 86 & 87 & 10 & $85^{2}$ & $94^{8}$ & 1090 & .087 \\
\hline Nat. Revenue & 24 & 18 & 3 & 87 & 114 & 1147 & .0099 \\
\hline Public Works & 70 & 46 & 619 & 335 & 1023 & 1209 & .085 \\
\hline Regional Ind. Exp. & 3 & 100 & 28 & . & 31 & 1855 & .0017 \\
\hline Science \& Technology & 3 & 54 & $<1$ & & 3 & 809 & .00037 \\
\hline Secretary of State & 3 & o & & 2 & 5 & 759 & .00066 \\
\hline Solicitor General & 1180 & 61 & 35 & 282 & 1497 & 1594 & .094 \\
\hline Supply \& Services & 3 & 100 & I & & 4 & 418 & .00096 \\
\hline Transport & 2313 & 11 & $3^{85}$ & & 2698 & 3221 & .084 \\
\hline Treasury Board & & o & 12 & & 12 & $5^{6} 5$ & .0021 \\
\hline Veterans' Affairs & 5 & 62 & $<1$ & & 5 & 1509 & .00033 \\
\hline $\begin{array}{l}\text { Totals and weighted } \\
\text { averages }\end{array}$ & 6777 & 30 & $293^{8}$ & 1424 & 11139 & $3^{8120}$ & .029 \\
\hline
\end{tabular}




\begin{tabular}{lcc} 
& $1983-4$ to $1984-5$ & \\
\hline & $\begin{array}{l}15 \\
\text { Increase in } \\
\text { payments } \\
\text { (percentage) }\end{array}$ & $\begin{array}{l}\text { Increase in } \\
\text { annual appropriation } \\
\text { (percentage) }\end{array}$ \\
\hline Agriculture & 68 & 31 \\
Communications & 128 & $5 \cdot 9$ \\
Consumer \& Corp. Affairs & 0 & 6.8 \\
Employment \& Immigration & -74 & 33 \\
Energy, Mines, Resources & 863 & -8.9 \\
Environment & -48 & 12 \\
External Affairs & -97 & $7 \cdot 3$ \\
Finance & 7500 & 6.1 \\
Fisheries \& Oceans & 481 & 12 \\
Indian \& Northern Dev. & -48 & 15 \\
Nat. Defence & -19 & 27 \\
Nat. Health, Welfare & 1835 & -57 \\
Nat. Revenue & 307 & 19 \\
Public Works & 99 & 14 \\
Regional Ind. Exp. & 1450 & 23 \\
Science \& Technology & -80 & 15 \\
Secretary of State & -44 & $9 \cdot 7$ \\
Solicitor General & -10 & 8.8 \\
Supply \& Services & -99 & 4.9 \\
Transport & 47 & 5.8 \\
Treasury Board & -29 & 7.8 \\
Veterans' Affairs & -55 & \\
Totals and weighted averages & 12.4 & \\
\hline
\end{tabular}

unlikely that the budgetary process would entail financial recognition of particular legal liability costs.

\section{THE STATE'S CAPITAL MARKETS}

One explanation of the data is that the constraints on the ability of governments to raise funds are radically different from the constraints that efficient capital markets theoretically place on private firms. If we relax the assumption that the state will react to liability risks in the same manner as a private firm, it is not as clear that the adoption of a direct state liability rule is desirable - and it is fair to say that the assumption is difficult to support. It is trite that central governments are not constrained by the same markets as private economic actors, and thus effective public policy analysis of government liability should employ very different assumptions. ${ }^{156}$

156 I point out later that if attention is focused on municipal governments, fiscally independent sub-units of governments, and the like, the effect of liability rules is more likely to track the effect I predict in private markets. 
Our ability to use economic sanctions in the case of private firms is effectively limited by several factors, including a restriction on the size of sanctions in view of our ideas about equal treatment, the social costs of bankruptcy if damage awards are raised to a sufficient level, and the increasing marginal costs of increasing fines coupled with decreasing marginal benefits. ${ }^{157}$ It is equally true that the utility of economic sanctions in the case of the state will be limited by a range of factors, which, while different from those operating in the private sector, are equally relevant to our analysis. In the end we must begin to think about the way in which the state reacts or will react to economic signals imposed by courts.

One assumption underlying the response of private firms to economic signals is that competition among private firms in capital markets defines winners and losers, and hence inefficient or efficient behaviour. Governments, however, are the only game in town, and that town is unique. Although comparisons between different administrations in different jurisdictions are undoubtedly valuable, such comparisons, given the differing political climates, resource bases, histories, and social situations of nations, can never be definitive of 'efficient' action. Therefore, the state is not subject to the constraints of a capital market, and it is unable to apply the lessons that have been learned by private firms in the competition for capital.

Decisions to allocate losses in governments must be sensitive to the appropriation process by which administrative units obtain their capital requirements for current and future programs. Under certain assumptions we might think that administrative units will be responsive to liability rules. That is, we might assume that competition among bureaucracies for legislative appropriations is analogous to the competition of private enterprise in capital markets. ${ }^{15^{8}}$ Government appropriation decisions would reflect an assessment of the return to the social welfare on the public's capital investment for the previous budgetary period, and the public's prediction of its expected return for the current period. Where the appropriation process operates in this fashion, the imposition of losses will result in a reduced ability of the bureaucracy to raise funds. Damage payments and associated transaction costs associated with tort claims will reduce the regulatory benefits otherwise achievable by the relevant depart-

157 See Kraakman, supra note 71, 881. Many of these ideas are developed by Christopher Stone in Where the Law Ends: The Social Control of Corporate Behaviour (New York: Harper and Row 1975) chapter 6.

${ }_{15} 8$ See R.A. Posner 'The Behaviour of Administrative Agencies' (1972) 1 J. of Legal Studies $30_{5}$, at 323-44, and Posner 'Theories of Economic Regulation' (1974) 5 Bell J. Econ. 335 . 
ment. ${ }^{159}$ To the extent that the ability of particular units to obtain capital is influenced and monitored by the suppliers of financial resources, we can expect that the imposition of liability will have incentive effects.

One immediate problem with applying this model is the difficulty in measuring the inefficiencies associated with government negligence. It is almost impossible for owners of the state to assess whether their agents are generating maximum returns on their 'tax' investments. If citizens could evaluate outputs, then inefficient inputs (which would include social costs associated with the production of public goods and which would be reflected in a reduction of outputs) could be monitored and responded to in the same way that actors in finance markets respond to inefficiencies in private firms. In that world we would enjoy the perfectly efficient state (whatever that means), and liability rules would be irrelevant.

It is safe to assume that what I call 'political capital markets' represented by the activities of senior bureaucrats and politicians, as agents of taxpayers, in monitoring and evaluating the return on public investments - are substantially less efficient than capital markets are in the case of private investments. For example, under the accountability mechanisms developed from the Lambert Commission recommendations, ${ }^{160}$ the allocation of resources through the budgetary process involves two stages. The first is the establishment of priorities and overall expenditure and revenue figures by centralized federal authorities; the second is the allocation of revenues among competing departments and programs employing the so-called envelope system. The overall level of expenditure is determined in the light of government fiscal strategy and available projected revenues, and then resources are allocated through competition among various policy committees representing departments and agencies. While this budgetary allocation process may result in the alignment of departmental budget proposals with overall fiscal policy, it fails to deal with the problem of ensuring that losses allocated to a particular department influence budgetary appropriations.

159 See C.R. Wise 'Liability of Federal Officials: An Analysis of Alternatives' (1983) 45 Pub. Admin. Rev. 746, at 751 . Wise suggests that, in the context of developing an indemnification fund for individuals who commit constitutional torts, the charges that each agency incurs should appear on their budgets, and that an officer of the Office of Management and Budget should be on the fund's board. See also S.G. Hadden (ed.) Risk Analysis, Institutions and Public Policy (Port Washington, NY: Associated Faculty Press 1984) 5, 34-5, 64-5.

160 The Royal Commission on Financial Management and Accountability (the Lambert Commission) was appointed in 1976 to examine financial management policy and practices in the federal bureaucracy, with specific reference to effective financial accountability. The commission issued its report in 1979: Final Report, Royal Commission on Financial Management and Accountability (Hull, PQ: Canadian Government Publishing Centre 1979). 
The federal government expenditure budget process begins approximately one and a half years before the fiscal year for which the budget is intended. ${ }^{161}$ It involves negotiations within a department, with the Treasury Board Secretariat, and with the Treasury Board itself, and continues through the fiscal year in which the budget is actualized through supplementary estimates. ${ }^{162}$ A departmental budget consists of two major components. The first is an a budget, which funds existing programs at the same level as the previous fiscal year, taking changes into account. It includes regular operating expenditures, including damage claims against the Crown arising out of the departmental activities. The second is a в budget, which comprises proposals for new funds required for the implementation of new programs or the enhancement of existing ones. In practice, the A budget is seldom closely scrutinized, except intradepartmentally when an assessment of a long-standing program is undertaken, usually with a view to enhancing the program or replacing it with a more extensive one. The $\mathrm{A}$ budget programs are rarely analysed, as in zero-based budgeting, to determine present efficiency. ${ }^{163}$ Until very recently, the A budget submitted by line departments representing current program allocations was considered politically sacrosanct, and only the B budget representing proposed programs would be subject to budgetary review in any meaningful sense of the term. ${ }^{164}$

Even assuming that damage claims were allocated to the appropriate unit with government, it is likely that they would be considered expenditures related to ongoing programs, and would simply be ammunition for increased A-budget allocation arguments. In the end, losses would be passed on to owner-taxpayers. ${ }^{165}$ Thus, the incentive effects of liability rules must be predicated on implementing budgetary reforms to ensure a level of scrutiny that would reveal legal liability risks. Incentives will be generated only if we design a system to appraise and measure program results (including tort losses), and link those results to the budgetary process. In other words, for losses to be internalized, program execution

161 Hartle, supra note $154,34-6$. This description is accurate, even taking into account the significant procedural and structural reforms of the budget setting and review process that have taken place in recent years. See Hartle 'The Expenditure Budget Process of the Government of Canada: A Public Choice-Rent-Seeking Perspective' Canadian Tax Paper no. 81 (Toronto: Canadian Tax Foundation 1988) 101-7 and 134-47.

162 Hartle, supra note $154,34^{-6}$

163 Ibid. $38,41,42-3$

164 See A. Wildavsky The Politics of the Budgetary Process 3 d ed. (Boston: Little, Brown 1979) and G.B. Doern and R.W. Phidd Canadian Public Policy: Ideas, Structure, Process (Toronto: Methuen 1983) 262-3.

${ }_{165}$ It is likely that other aspects of the Lambert Commission proposals dealing with policy and expenditure management and with accountability within the public service would, if properly implemented, reduce that problem. 
- the delivery of regulatory benefits (with their associated costs) - must be linked to resource allocation in the budgetary process. ${ }^{166}$

A slightly different perspective on the response of the government to liability focuses on the choice of payment mechanism, which theoretically offers an alternative source of regulatory control. Federal Court awards are defined as statutory payments pursuant to the Federal Court Act, and damage awards ordered to be paid by the federal government in Federal Court judgments are paid out of the consolidated revenue fund. ${ }^{167}$ The Public Accounts records judgments by department, but the funds paid out of the consolidated revenue fund are not charged to particular departmental budgets. ${ }^{168}$ Unless internal administrative steps are adopted to allocate this loss to a particular department or other subsidiary of government, it is unlikely that the risk of liability will be relevant in departmental decision-making.

The impact of liability rules may also be influenced by the design of the settlement process within government. A range of institutional and procedural mechanisms regulate settlements of Federal Court claims, and it is clear that the impact of liability rules will be influenced by the design of the settlement process in government institutions. ${ }^{169}$ Under the claims regulations enacted pursuant to the federal Financial Administration Act, ${ }^{170}$ settlements of claims where the total amount of all claims arising out of the same matter is less than $\$ 200,000$ can be made only by

166 In a sense, the Lambert Commission recognized that some link was necessary, but the overall impression one gets from the report is that the central authorities should leave management to management. The commission suggests that after allocating resources to departments, the central expenditure-allocating authority should permit 'individual departments and agencies to manage their affairs in a way that will best achieve the objectives assigned to them with the resources available': Final Report, supra not 148 , 64 .

None the less, the commission did recognize that effectiveness-evaluation of programs was necessary, and recommended the establishment of a Board of Management to replace the Treasury Board, with responsibility lodged in a Financial Management Secretariat to ensure the effective management of departmental and agency financial resources. See O.P. Dwivedi 'On Holding Public Servants Accountable' in O.P. Dwivedi (ed.) The Administrative State in Canada (Toronto: University of Toronto Press 1982) 159.

167 RSC 19702 d Supp., c. F-10, ss. $55^{(2)}, 57(3)$, and 52

168 Telephone conversation 4 July 1986 with M. Duffy, Toronto regional office of Federal Department of Justice

169 It is a fair assumption that the number and magnitude of settled claims far exceeds the number and financial impact of court judgments.

170 Claims Regulations, CRC 1978, c. 683, amended soR/82-205, pursuant to the Financial Administration Act, RSC 1970, c. F-10, s. 6 . The claims regulations cited above indicate a limit of $\$ 50$,ooo. However, Robin Findlay of the Office of the Controller General, in a discussion with me on 15 July 1986 , indicated that the limit was raised to $\$ 200$, ooo to reflect enhanced ministerial responsibility. See sor / 86-10 14 , part II Canada Gazette vol. 120 , no. 22. 
the department after an opinion is obtained from the deputy attorney general. Claims exceeding $\$ 200,000$ are payable only with Treasury Board approval. In practice, however, claims are 'settled' by means of consent orders from Federal Court judges, which, like Federal Court awards, ${ }^{171}$ are paid out of the consolidated revenue fund, and do not have an impact on specific departmental budgets. ${ }^{172}$

Unless internal administrative steps are adopted to allocate these settlement payments to a particular department or other subsidiary government unit, it is unlikely that the risk of liability will be relevant in departmental decision-making. Assuming that the response of a department to economic risks that are focused on its budget is different from its response when the risks are shifted to the consolidated revenue fund, the impact of liability rules will differ, depending on the magnitude of the losses they generate. Under the current settlement processes, relatively small losses may have substantially greater effects on departmental behaviour than significant losses that are allocated to general revenues. As a general policy, the internalization of social costs is likely to be achieved only if both damage awards and settlements are paid out of departmental budgets and are not shifted to general revenues.

Finally, there are damage claims that are made against particular departments but are not pursued through the Federal Court. Demands for compensation from the government in situations where liability may be impossible to establish, or where liability on the government's part is non-existent, but where, for unarticulated reasons, compensation is indicated, may be dealt with through a system of formally authorized $e x$ gratia payments. These payments are not made as a response to potential legal liability, and, like damage awards and settlement 'consent' orders, are made out of the consolidated revenue fund. ${ }^{173}$

The ultimate financial control of all of these government expenditures - that is, ex gratia payments, damages awards, and settlements - resides with the Treasury Board, which is made up of five ministers of the Crown. ${ }^{174}$ The secretariat of the Treasury Board provides the board with

171 Telephone conversation, 7 July 1986 with Paul Olivier, secretary to the Commission of Inquiry into Certain Banking Matters, and retired associate deputy minister of the Department of Justice

172 Similar institutional mechanisms operate in the United States under the Federal Tort Claims Act, 28 usc, ss. 2672,2677 , and 2678 (1970). This act permits an agency to settle claims up to $\$ 25,000$, and it seems that costs up to $\$ 25$, ooo would be allocated to the agency budget. These claims are not subject to an opinion from the Justice Department. Larger claims are paid from general revenues, but for claims greater than $\$ 25$, ooo a legal opinion from the United States Department of Justice is required.

173 Robin Findlay, supra note 170

174 Financial Administration Act, supra note 17o, s. 3(2) 
the detailed information and budgetary analysis necessary to support the board in its decisions. ${ }^{175}$ While secretariat resources might be used in establishing a feedback mechanism for damage awards, discussions with the Treasury Board's financial officer to the Department of Justice indicate that the board does not undertake a careful examination of specific financial losses associated with legal liability. Such monitoring would be expensive, and, given the magnitude of current exposure, yields data that are of minimal relevance to the funding decisions of the Treasury Board. ${ }^{176}$ Furthermore, discussions with the Treasury Board's expenditure analysis group indicate that in general there is no assessment of settlement payments. The Treasury Board analysis has usually focused on macroeconomic issues and has not been applied to expenditures of the type and magnitude associated with current legal liability risks. ${ }^{177}$

In addition to the potential impact of awards and settlements, legal liability risks might be signalled through the impact of the cost of legal services. All departments retain legal counsel whose function is much like that of lawyers employed by private firms: the department acts as a client, and decides how and whether to use counsel's advice. ${ }^{178}$ Almost all litigation, however, is undertaken by Department of Justice lawyers. ${ }^{179}$ Payment of large settlements and litigation decisions are made after consultation between the departments. None the less, it seems clear that the legal expertise of Department of Justice lawyers predominates, and the conduct of litigation is controlled by that department. ${ }^{180}$ The Department of Justice funds the litigation, and other departmental budgets are not affected by the costs of litigation services. ${ }^{181}$

One can conclude that the collective impact of the current treatment of legal liability costs to the government (which includes budgetary allocation mechanisms, Treasury Board review, the payment of damage claims, settlements, and ex gratia payments from the consolidated revenue fund, and the allocation of legal costs to the Department of Justice) presents the

175 Hartle, supre note 154,15

176 L. Endemann, supra note 155

177 Telephone conversation 15 July 1986 with F. Lane, group chief of expenditure policy and planning analysis of the Treasury Board

178 Telephone conversation 14 July 1986 with $\mathrm{Mr}$ Heiss of the legal department of Transport Canada

179 An exception is tax litigation, where the Department of National Revenue employs its own litigation specialists. Departments will also pay out of their own budgets for private sector legal advisers hired on an ad hoc basis: L. Endemann, supra note 155 .

180 Paul Olivier, supra note 171

181 An officer of the Treasury Board's expenditure analysis group stated that there was no assessment of legal work costs or the payment of settlements. The allocation of legal costs would be subject to negotiation between individual departments and the Department of Justice: F. Lane, supra note 177. 
government with a 'capital market' very different from that faced by private firms. The description of these mechanisms suggests that legal liability will have only attenuated incentive effects in the absence of additional mechanisms within government which would reallocate that liability to individual departmental budgets. No institutional mechanism currently operating within the federal government bureaucracy achieves that goal. Any reduction in primary accident costs would require much more sensitive financial control in government, as well as the uncoerced co-operation of the relevant departments.

\section{LIMITING FACTORS}

Even if we were to redesign the budgetary approval process, link it with auditing procedures that revealed contingent liability risks, and allocate damage claims, settlement costs, ex gratia payments, and legal expenses to specific departments, we would still have to recognize the limiting factors that operate in the case of governments (but do not operate in the case of most private firms) and that influence our ability to use tort law as a regulatory instrument. ${ }^{182}$

One critical factor affecting the instrumental impact of liability awards is a reflection of the non-market characteristics of many public services and goods. Those characteristics may mean that output reductions may not occur in response to legal liability costs. We assume, in the case of private firms, that increases in costs associated with liability awards, to the extent that they are not reduced efficiently, are reflected in the price of the firm's goods. ${ }^{183}$ As the price increases, demand is reduced, and the absolute number of goods in the market will decrease. As the number of goods decreases, aggregate accident costs also decrease.

However, governments often use non-market vehicles to distribute public services. In such cases the output price may be zero; even when it is not, in many cases the output price bears little or no relationship to cost. ${ }^{184}$ If that is so, even if social costs represented by damage awards were 'internalized' to the government, there might not be any concomitant reduction in output, and thus no reduction in accident costs associated

182 Many of these points reflect the 'bureaucratic' element of public bureaucracies, and thus are equally applicable to private, corporate bureaucratic conduct. See C.D. Stone Where the Law Ends (New York: Harper and Row 1975) especially at 93-118.

${ }_{183}$ That is, a firm faced with potential legal liability will take cost-effective accident reduction measures to the point that the marginal benefit associated with the measures equals the reduced liability exposure. All losses that are not thus avoided will be incurred, and the price at which goods are sold will reflect both the cost of the efficient accident-reduction-measures and the residual liability risks.

184 See W.F. Baxter 'Enterprise Liability, Public and Private' (1978) 42 Law E' Contemp. Prob. 45, at 51. 
with increased prices. In addition, it is not clear that it would be desirable, given the objectives of the government programs, to reduce output even if we would otherwise want to. Decision-makers who impose legal liability on the government in an effort to reduce primary accident costs should take into account that this element of primary accident costs reduction may be absent in the case of state action.

A second limiting factor influencing the desirability of using tort law to regulate public bureaucracies is the ability of the government to shift the losses back to victims or other members of the public through retroactive legislation. Perhaps the best-known example of this was the decision, made first by the Tory government and then by the Labour government, to enact the War Damage Act ${ }^{185}$ in England in 1965 . That act retroactively abolished the common law right to compensation for damage to property associated with acts carried out by the government during or in contemplation of the outbreak of war. The legislation was enacted in response to a 1965 decision of the House of Lords in Burmah Oil Co. Ltd v. Lord Advocate ${ }^{186}$ which had recognized a claim for over $\$ 100$ million dollars arising out of the destruction of the claimant's property during the British retreat from Rangoon in 1942. The risk of such state retaliation might be small, but it strengthens my thesis that attempts to internalize losses associated with state action cannot be modelled on liability rules designed for private firms.

The idea represented in Burmah Oil is central to an understanding of the efficiency of government liability. The evaluation of compensation payments and their associated incentive effects should acknowledge that state liability necessarily involves the judiciary's directing the investment of public resources in risk-reducing measures or compensation payments that would otherwise be allocated to achieving agency objectives. One can expect that the agency will have a comparative advantage in determining when the marginal costs of accident reduction investments exceed the associated marginal benefits of those investments, and when alternative uses of the resources will optimize social welfare. ${ }^{187}$

A third limiting factor is the willingness and ability of the government department or the government as an institution to shift losses to its 'owners' - that is, the tax-paying public. If the government is not

1851965, c. 18

$186[1965]$ AC 75 . Apparently, the legislation was also motivated by the existence of several other potential claimants in the same position as the Burmah Oil Company. See Note 'The Burmah Oil Affair' (1966) 79 Harv. LR 614 .

187 This also assumes away the distorting effects of bureaucratic self-interest discussed in the public choice literature. See the text accompanying notes $98-111$ supra. 
constrained to operate at optimal levels of taxation ${ }^{188}$ and to adopt optimal monetary policies, then all losses shifted to the government by the courts can be shifted to the community, subject only to the marginal cost in lost votes. If one assumes that tax and monetary policy as currently formulated does not operate within constraints that are relevant at the marginal dollar levels represented by tort losses, then liability rules applied to governments ${ }^{189}$ will have no impact on the behaviour of bureaucrats, and will merely generate substantial transaction costs as wealth is shifted from one group of (tort) victims to a second group of (tort law) victims. ${ }^{190}$

One way to understand whether and why the government will be likely to pass on 'tort' costs is to evaluate the motives of the bureaucratic agency. One model of bureaucratic organization postulates that bureaucracies seek to maximize their expenditures. ${ }^{19^{1}}$ In the absence of devices that use the tax structure to control the 'tendencies of government to grow without bound' ${ }^{92}$ or effective central bureaucratic or legislative review to monitor and regulate particular bureaucratic budgets, agencies that conform to this model will always pass regulatory tort costs on to the tax-paying public. In fact, if the judgment requires funds not currently appropriated, the judicial order is implicitly directed against the legislatures or other governmental unit controlling the expenditure process. Merely awarding damages in these cases would only justify demands for additional bureau funding. ${ }^{193}$ If one assumes this model of government, then liability rules will not generate increases in allocative efficiency.

A different model of bureaucracy that can be applied to predict the

188 Even if it were, it would be unrealistic to expect the courts to determine what the optimal level of taxation is, and even more unrealistic to think that the courts could determine whether the government was operating at the optimal level. There is nothing which requires that we use courts as the review institution, but there is no obvious institutional candidate that would be able effectively to carry out those tasks.

189 As discussed earlier, funds paid out in tort claims are taken from the consolidated revenue fund. Under section $17(2)$ of the Federal Court Act, supra note 167, all damage awards against the federal government are allocted to the consolidated revenue fund.

190 The extent to which the state will pass costs on to the public depends on a number of subsidiary variables, including taxation policy, fiscal policy, and the impact of taxation decisions on investment, production, voting behaviour, and so on.

191 This model was developed more fully in part 2. See W.A. Niskanen Jr Bureaucracy and Representative Government (Chicago: Aldine, Atherton 1971) and Niskanen 'Bureaucrats and Politician's (1975) $18 \mathrm{~J}$. of Law and Econ. 617.

192 Mueller, supra note 23,167

193 See Edelman v. Jordon 415 U.s. $65^{1}$ (1974) (decision to fashion award as a retroactive injunction against state official requiring agency to dispense funds from treasury, reversed). See Yudof, supra note 69,1349 et seq. 
response of the government to the imposition of regulatory tort costs is one in which bureaucrats are motivated to maximize their personal welfare. In this world bureaucrats are expected to make choices that will increase personal income, personal and institutional power, or personal ideals of the public good. ${ }^{194}$ Bureaucracies conforming to this model may develop efficient accident-reduction policies - but only when the victims of accidents are able to organize effectively and bring political pressure (costs) to bear either directly on the relevant bureaucracy or indirectly on political actors who are able to influence bureaucratic activity. ${ }^{195}$ If the actual and potential tort victims are not easily identifiable or are widely dispersed, poorly organized, and politically unsophisticated, bureaucratic agencies that conform to this model probably will remain immune from the effect of liability rules.

One might argue that liability rules coupled with constraints on taxation which preclude passing regulatory costs on to taxpayers (if combined effectively) would provide the necessary incentive on the part of agencies to develop and implement accident-reduction policies. The use of the tax system to constrain bureaucracies ${ }^{196}$ suffers from the obvious defect that we cannot always view government as a grasping Leviathan, and that legitimate welfare-maximizing and redistributive government objectives may demand specific levels of taxation. Given a range of possible government models and motives, the blunt instrument of a tax constraint as a solution to the unconstrained costs of bureaucratic negligence does not appear to be justified.

A fourth and final limiting factor on the use of tort law as a regulatory

194 This model was described in part 2. It is developed more fully in A. Downs An Economic Theory of Democracy (New York: Harper 1957), and G. Tullock 'Problems of Majority Voting' (1959) $67 \mathrm{~J}$. of Pol. Econ. 571.

195 As I point out later, however, it is quite likely that the ability of superior bureaucrats to control effectively the activities of line officers is overestimated. A more important point is that this model posits that the regulatory impact of tort law is a product of political variables - the imposition of political costs, and the signalling of potential political responses - and not of economic costs and signals. If that is so, it is equally plausible that we do not need economic signals at all, and thus the design of a regulatory instrument effective against governments should focus on political rather than economic incentives. I develop the signalling model of government liability in part $\mathfrak{5}$.

196 G. Brennan and J.M. Buchanan 'Towards a Tax Constitution for Leviathan' (1977) $8 \mathrm{~J}$. of Pub. Econ. 255. Unlike most analyses of tax policy, Brennan and Buchanan do not postulate a fixed amount of revenue as being necessary to achieve public policy objectives. They suggest that the government be limited to taxing the more elastic tax bases, that certain inelastic tax bases be sheltered from taxation entirely, and that taxes be imposed on all persons equally to limit the government's ability to discriminate and thus expand its revenue. As Mueller puts it, "horizontal equity" would be favoured ... because it limits the government's degrees of freedom, and not for any other ethical reasons': supra note 23,169 . 
instrument is the inability of large bureaucracies to respond to liability rules even if some individual bureaucrats are motivated to do so. Although economic costs generated by liability rules are relevant to superior bureaucrats whose budgets are constrained and who are motivated to minimize social costs, those superior bureaucrats will also respond to internal political risks. Those risks may manifest themselves in reorganization costs or bureaucratic hostility to change, both of which may present substantial countervailing incentives, resulting in a failure to respond to liability risks imposed by an exogenous review institution. ${ }^{197}$

The inability of agencies to respond to legal liability rules is exacerbated by an asymmetry between the incentives faced by low-level bureaucrats and those faced by senior bureaucrats who are confronted with liability claims. For example, a municipal police department that is confronted by internal disciplinary measures in response to legal liability may respond by organizing and working to rule or engaging in work stoppages. ${ }^{198} \mathrm{~A}$ study of the Detroit police force, which documented 'unprecedented' damage payments, concluded that obtaining co-operation from police officers was extraordinarily difficult in view of the interests of the police officers in continuing their current practices. ${ }^{199}$ Paradoxically, superior bureaucrats are likely to respond to internally generated costs associated with their attempts at program modification. ${ }^{200}$ If the expected internally generated costs exceed the expected tort costs, the downward signal generated by tort claims will be significantly distorted. ${ }^{201}$ The process of regulating bureaucracies is expensive, time-consuming, uncertain, and potentially embarrassing. Moreover, it may significantly affect depart-

197 For example, in Connecticut the existence of section 1983 damage actions apparently did not affect police department practices, partly because the attitude at superior departmental levels was typically one of complete support for line officers, and partly because of the political dependence of municipal officials on police agencies. See 'Suing the Police in Federal Court' supra note 42, 813,814.

In Owen v. City of Independence 445 U.s. 662 (1980) and Payton v. United States 636 F. $2 \mathrm{~d}$ $132(1981)$ the court expressed the view that the potential threat of government liability was of limited relevance to officials, particularly when they perceived their department as strongly supporting their actions.

198 Schuck, supra note 57,139

199 Littlejohn, supra note 17,4 o9-10

200 Schuck admits this when he refers to the difficult senior bureaucrats experience in trying to influence the street-level bureaucrats' behaviour, given the 'intense spirit, loyalty and respect' engendered among government employees working in street-level departments: Schuck, supra note $57,106$.

201 Furthermore, the idea that information is distorted as it moves up through bureaucratic organization applies with equal force to information moving down. In addition, the internal bureaucratic costs will, by definition, be borne by the agency and superior bureaucrats, while the economic costs of damage awards are likely to be charged to consolidated revenue funds. See the text accompanying notes $167^{-1} 7^{2}$ supra. 
mental morale and produce additional conflict with co-workers, unions, program beneficiaries, and politicians. ${ }^{202}$

\section{v Possible solutions}

If one accepts that only the net marginal benefits of liability rules count, it may be possible to design liability rules that take into account the ability of governments to pass on tort costs and to respond effectively to liability risks. It may be argued that there are some general distinctions, which, while imperfect, can be relatively easily applied, and which might generate optimal liability rules in a limited subset of cases. For example, liability rules might recognize that government is not a monolith, and that it is itself structured through departments, Crown corporations, independent administrative agencies, program units, units with geographical or geopolitical responsibilities, public hospitals, and so on. With that in mind, one might assume that some of these sub-units will attempt to maximize profits, and thus should operate subject to liability rules analogous to those applicable to private economic actors. That is, it is superficially attractive to propose that liability rules should be used as a loss-internalizing instrument for a limited subset of 'efficient' state actors. ${ }^{203}$

This proposal assumes that state institutions may be 'efficient' in two very different senses. In part II I argued that 'efficient' bureaucratic decisions represent choices motivated by an interest in maximizing social welfare, and, to the extent that they achieve that objective, it is not appropriate or feasible to subject them to liability rules. At the same time, in a limited set of cases, it can be assumed that the state will be motivated to maximize its own private welfare, and to the extent that it achieves that objective it will be 'efficient.'204

An example of this second category of state actor, for which liability rules might be appropriate, is a state enterprise that is engaged in delivering goods and services through a market vehicle, that is relatively independent of central bureaucracies, and that has adopted a corporate model of economic organization traditionally employed by private economic actors. Here it might be assumed that the state is seeking to maximize its private welfare to some degree. In this case, as in the case of

202 Mashaw, supra note 59,23

203 This argument is applicable both to a limited subset of bureaucracies that are in fact efficient and to a related subset of bureaucracies that are merely motivated by efficiency criteria but fail to achieve either superior or optimal outcomes.

204 While it may be legitimate to assume that both models of state action are currently reflected in bureaucratic practices and organization, it may also be impossible to distinguish one from the other, and in some instances, bureaucratic action will reflect mixed motivations. 
private firms, tort law may appear attractive to ensure that the state enterprise responds to the social costs of its activities. ${ }^{205}$ In other words, in designing optimal liability rules we might try to distinguish between state actors that are motivated by social welfare-maximizing objectives (and are efficient in that sense) and to which a 'no liability' rule should be applied, and state actors that are motivated by profit-maximizing objects (and are efficient in that different limited sense) and to which either strict or fault liability rules should be applied. ${ }^{206}$

That idea is embodied in the approach that has been taken by the courts in treating Crown corporations engaged in 'non-governmental' activities as private firms, and thus denying them traditional governmental immunities. ${ }^{207}$ If one can identify state actors motivated by private wealth-maximization objectives, liability rules designed to internalize social costs appear superficially attractive. ${ }^{208}$ If we determine that a particular loss was associated with actions motivated by private welfare motives, this proposal requires liability rules that would force the state enterprise to take into account the social costs of its activities; in this case, the public enterprise would be indistinguishable from a private firm.

While this approach is frequently advocated by proponents of an expanded government liability, it presents several intractable problems. At the very least one would have to determine whether the particular subject of review was efficient in attempting to achieve socially optimal outcomes $^{209}$ or if it was efficient in seeking to maximize its private

205 See Spitzer, supra note $5,527$.

206 The public enterprise acts like a private firm in terms of its treatment of social costs (that is, it tries to externalize them), but this does not mean that it will respond to liability rules in the same way private firms can be expected to. If public enterprises are inefficient relative to private firms whose management is subject to monitoring through capital markets, there is no reason to think that these agency costs are the result of the public enterprise's having internalized social costs.

207 Trebilcock and Prichard, supra note 25, 18 . The cases on this point are voluminous: see Halifax v. Halifax Harbour Commission [1935] SCR 215; Radych v. Manitoba Power Commission [1942] 2 DLR 776 (Man. CA); R. v. OLRB exparte Ontario Housing Corp. (1971) 19 DLR (3d) 47 (Ont. HC); MacLean v. Liquor Licence Board of Ontario (1975) 61 DLR (3d) 237 (Ont. HC); and Bodrug v. Manitoba Housing and Renewal Corp. et al. (1977) 79 DLR (3d) 409 (Man. QB). See also C.H. McNairn 'The Ontario Crown Agency Act' (1973) 6 Ottawa $L R 1$ and Peter Hogg The Liability of the Crown in Australia, New Zealand, and the United Kingdom (Melbourne: Law Book Co. 1971) 203-8,212.

Of course, if these public firms are integrated into government activities, the courts may treat them as government and immunize them from tort liability: Baccus $S R L \mathrm{v}$. Servicio Nacional del Trigo [1956] 3 All ER 715 (CA) Swiss Israel Trade Bank v. Government of Salta [1972] 1 Lloyd's Rep. 497, at 507 (QB) (separate legal entity carrying on commercial activities not an organ of government).

208 See J.L. Sax 'Takings and the Police Power' (1964) 74 Yale LJ 36, at 63-7.

209 As I argued earlier, if we concluded that the agency was motivated to maximize social welfare we then would determine the extent to which the socially optimal result was achieved. To the extent that it was not achieved, liability rules would be used to correct inefficiencies associated with the decisions. 
welfare. ${ }^{210}$ It is not clear to me that this determination can be made without incurring substantial costs.

Furthermore, even if we determine that the public enterprise was motivated to maximize profits, we may want to recognize its 'public' aspect; and if the public firm is acting in part as a social welfare-maximizer, we do not want to oblige it to internalize social costs it has already taken into account. ${ }^{21}$ Moreover, if we apply liability rules in this subset of cases, we can predict substantial investments by victims in arguing that the public corporation was acting in a 'business' capacity, and by the government in demonstrating that the firm was exercising 'governmental' powers. ${ }^{212}$ Formal tests would be inadequate, for government might legitimately argue that while the enterprise was organized as a public firm its operations were in fact those of the government, thus making the implicit argument that the enterprise was acting in a social welfaremaximizing mode. ${ }^{213}$

We could propose that a public enterprise should always be treated like a private economic actor, but we must then admit that we may be allocating losses to the firm that already have been internalized. Moreover, if we establish a formal rule that departments will be immune from liability while public corporations will be treated like private firms, we create artificial incentives for the government to choose the former over the latter as a policy instrument.

An inability to distinguish among a range of bureaucratic models that may be operating at any given time suggests that a uniform liability rule applicable to all state enterprises is unlikely to generate optimal incentive structures. Even if it were possible to distinguish efficient from inefficient bureaucracies, it would still be necessary to inquire further into the precise form of efficiency operating in a particular bureaucracy. Further-

210 Furthermore, we must also be sensitive to the reality of a great deal of public enterprise: it may not conform to either model, but may reflect elements of both.

211 It is notoriously difficult, however, to disaggregate public from private motives in the mixed public corporation. See A. Boardman, C. Eckel, M. Linde, and A.R. Vining 'An Overview of Mixed Enterprises in Canada' Ch. 26 in K.J. Rea and N. Wiseman (eds) Government and Enterprise in Canada (Toronto: Methuen 1985); A. Tupper and G. Bruce Doern 'Public Corporations and Public Policy in Canada' Ch. 1 in A. Tupper and G.B. Doern (eds) Public Corporations and Public Policy in Canada (Montreal: Institute for Research on Public Policy 1981); S. Brooks, Who's in Charge? The Mixed Ownership Corporation in Canada (Montreal: Institute for Research on Public Policy 1987) at 11-19. 212 See G.F. Kugler Report of the Attorney General's Task Force on Sovereign Immunity (Trenton, $\mathrm{NJ} 1972$ ) at 39, 41. See also Berardinelli v. Ontario Housing Corporation (1979) 90 DLR (3d) 481, at 493 (SCC) McGonegal v. Gray et al. [1952] 2 DLR 161, at 170 (SCC); and Bradford Corporation v. Myers [1916] 1 AC 242.

213 This is the type of argument one sees in cases like Mellinger v. New Brunswick Development Corporation [1971] 2 All ER 593, at 596 (CA) and Swiss Israel Trade Bank v. Government of Salta [1972] Lloyd's Rep. 497 (QB). 
more, there is no reason to assume that all decisions within a particular bureaucracy are characterized by one form of efficiency or inefficiency in all situations. In fact, it seems that the administrative costs of drawing the distinctions at all these levels would make the entire exercise useless. If we cannot identify this subset of decisions at a reasonable cost, then a no-liability rule is optimal without additional self-regulatory responses by the state. ${ }^{214}$

An alternative solution to the limitations inherent in applying liability rules to government enterprises engaging in 'non-governmental' functions is to focus the economic signals generated by liability rules on sub-bureaus within government. In part I I considered only two objects of government liability - the individual bureaucrat and the government. ${ }^{215}$ In reality, and as a theoretical proposition, we can focus liability rules on any of a number of sub-units, and the incentive effects of legal risks are not identical for all possible units. For example, the extent to which governments can pass costs on to taxpayers may depend on the level of government - municipal, provincial, or federal - to which the losses are shifted by the court. In addition, one can impose liability on intragovernment units, since there is no reason to restrict ourselves to formal legal or political units; various proposals have been made to allocate liability to a point somewhere between the individual bureaucrat (exposing her personal wealth to liability risks) and the government (exposing general revenues to compensation claims).

If our aim is to signal information about losses associated with state action, we should design a liability regime that shifts losses to an intermediate node within government which has managerial, supervisory, and budgetary authority over the relevant activities. ${ }^{216}$ This reform would necessitate the recognition of non-corporate intragovernment units, but this does not seem to create insurmountable problems. ${ }^{217}$ If liability were imposed in this fashion, it is likely that the marginal benefits of liability would be maximized, and that the marginal costs generated by review errors and the administrative costs would be minimized.

This approach could involve several subsidiary elements, which would

214 That is because we would still be faced with the ability of governments to pass costs on to taxpayers, and we would still have to evaluate the impact of the political market in influencing the relevant bureaucracy to internalize losses and the marginal net benefits of the liability regime.

215 The possibility of imposing liability on superior bureaucrats as well as on line officers was discussed briefly, but there appears to be no advantage to using that liability regime. This point is discussed in part i supra.

216 See Mashaw, supra note 59, 34 and Schuck, supra note 57, 106.

217 See Northern Pipeline Agency v. Perehinec (1983) \& DLR (4th) I (scc) (legal identity inferred from status-allocating agency powers). 
increase its ability to influence government activity in the appropriate circumstances. For example, liability would be imposed when political markets were not working effectively, and on institutions that were not subject to centralized authority. We might anticipate that state actions would be directed at maximizing aspects of bureaucratic welfare, given our assumptions about bureaucratic motives in unregulated contexts. As well, we could link the liability regime to state activities that were only tangentially related to bureau objectives and expertise ${ }^{218}$ - 'in short, situations in which agency collection and use of information about employee negligence is costly or undervalued.' ${ }^{219}$ Moreover, if the power of the sub-unit of government to increase its budget is limited, as it is in the case of municipal governments, significant loss internalization may take place.

The experience of municipalities suggests that more refined models of government liability, in which liability is imposed at sub-bureau nodes, may in limited circumstances be an attractive regulatory instrument. ${ }^{220}$ In this model the reviewing institution identifies the sub-units within the bureaucracy that have budgetary, managerial, and supervisory authority over the bureaucrats whose activities are associated with the injury, and allocates liability at that point in the bureaucracy. If we are accurate in identifying that node, and if we prevent that bureau from shifting losses to other bureaus or to general revenues, we may effectively force the unit to internalize social costs. Although the idea is attractive, and is supported by recent experiences with municipal liability, the proposal has several shortcomings.

The most important is that bureaucratic budgetary, managerial, and supervisory authority may be allocated across several levels or units of government. In those cases it will be impossible to identify a single node on which to impose liability. For example, in the case of police torts, the enforcement responsibilities of the police, the institutional design of police forces, and managerial authority at the policy and operational levels cannot be allocated to a single government unit. Under the current federal tort regime, the federal government is not liable for the tort of municipal police officers, ${ }^{21}$ nor is the province. ${ }^{222}$ Thus, the two

218 In these cases, it is unlikely that redistributive judgments would be subject to review. 219 Mashaw, supra note 59,33

220 This model has been developed by Peter Schuck, supra note $57,100-46$.

221 Schulze et al. v. The Queen (1974) 47 DLR (3d) 131, 17 CCC (2d) 241 (FCTD) (municipal police officers are not automatically agents, servants, or employees of the Federal Crown under section 3(1) of the Crown Liability Act, RSC 1970, c. C-38).

222 See Allain v. Procureur General de la Province de Quebec [1971] CS 407, at 411 , and Attorney General for New South Wales v. Perpetual Trustee Co. Ltd [1955] I All ER 846 (PC). 
government institutions which through legislative and regulatory action significantly define the enforcement responsibilities of municipal police officers are immune from liability. Moreover, the courts have decided that municipalities in Canada (which directly or indirectly through police commissions manage municipal police forces, exercise management powers of hiring, firing, and disciplining police officers, and fund police services) are not responsible for the torts of police officers who are enforcing federal and provincial legislation. ${ }^{223}$

Given our interest in designing liability rules that will internalize accident losses; given the differential incentive effects of liability rules depending on the taxing powers of the governmental unit to which we direct liability; and given the mixed sources of authority and control over particular bureaus, identifying a sub-bureau within government is not as straightforward as one might think. One cannot assume that a bureau with budgetary control also will have supervisory and managerial authority over the relevant bureaucrats.

The concept of intragovernment liability assumes that the review mechanism can effectively preclude the shifting of the losses away from the bureau. The separate corporate existence, political status, taxing powers, and budgetary authority of municipal institutions suggests that in that limited area of state action the model might operate effectively. However, in the case of internal government departments, and subbureaus within departments, the model requires the creation of another bureau to monitor the subject bureau's budgetary allocations in current and future years to determine whether accident losses are being shifted. ${ }^{224}$ Only when public institutions are constrained by mechanisms

223 See McLeave v. City of Moncton (1902) 32 SCR 106, 6 CCC 219; Caratozzolo v. Mudock Ewatski and City of Edmonton (1982) 47 Alta. LR (2d) 394 (Alta QB); The Queen v. Labour Relations Board et al. (1955) 38 MPR 26 (NB); and Re St Catharines Police Associaton and Board of Police Commissioners [1971] 5 DLR (3d) 532, 1 OR 430 (Ont. HC). At the same time, the municipality may be vicariously liable to victims if the police officers acted as agents of the city in the execution of municipal by-laws, ordinances, and similar legislation. The municipality may be directly liable if it appears that it approved or directed the police activity: City of Montreal v. Plante (1923) 34 Que. KB 137; Hebert v. City of Thetford-Mines [1932] SCR 424, [1932] 3 DLR 583. While Ontario and several other provinces have enacted legislation modifying that presumption (see Police Act, RSO 1980, c. $3^{81}$, s. 24; Police Act, RSBC 1979, c. $33^{1}$, s. 54; Provincial Police Act, SM 1971 , c. 85 , s. 21 ; and Police Act, RSS 1978 , C. P-15, s. 48), municipal immunity continues in several provinces. Similar issues arise in the case of provincial police and the RCMP. In the latter case, the courts have held that federal officers are not employees of the provincial government. See Re Ombudsman for Saskatchewan [1974] 46 DLR (3d) 452, at 456-7, 5 WWR 1 76, at 179-8o (Sask. QB). But see Police Act, RSBC 1979, c. 331 , ss. 1, $16(2)$, and $53(1)$ (provincial government liable for torts of RCMP officers).

224 As discussed above, such internal institutional mechanisms are not operating within the federal government. See the text accompanying note $172 \mathrm{et}$ seq. 
comparable to those operating in capital markets can we anticipate the same loss-internalization impact of liability rules as in the case of private firms. ${ }^{225}$ The public review bureau designed to compel the internalization of social costs will generate its own administrative costs. In view of the nature of public budgetary allocations, it does not seem possible to distinguish requests for funds for new programs that will incorporate funds for accident losses from requests for programs that will not. Finally, the model assumes that the bureaucrats who will be responding to the signal are able to influence street-level bureaucrats in such a way as to reduce accident costs - and that, as we have seen, is not necessarily true. As well, the benefits of this model of liability must be assessed in the light of the impact of error costs in determining the relevant node. To the extent that errors are made, we will be creating inefficiencies that might easily offset the gains generated by the liability regime.

Even if we could expect intragovernment units to respond to liability risks, it is not clear that liability rules are desirable. First, we would have to determine whether the specific department or public enterprise was acting in an inefficient manner in respect of the particular activity that is associated with the loss, or in an efficient manner that mimics the activities of a private firm. ${ }^{226}$ If the sub-unit is acting inefficiently, we then have to determine which of the inefficient models best describes the activities that are relevant to the inquiry. Moreover, attempts to allocate losses to a particular sub-unit within a bureaucracy may give rise to the externalization of losses associated with interinstitutional actions, which justified direct government liability in the first place. Even if the distinctions could be drawn, the administrative costs generated by the rules would be substantial.

Only if tort losses are allocated to intrabureau units; only if those intragovernment bureaus are not permitted to pass the costs upwards to general revenue funds through budgetary appropriations over time; only if the bureaus do not take into account social costs ex ante; and only if the

225 There are two points to be made here. First, the economic independence of many public enterprises, including Crown corporations, is a question of degree, as is the economic independence of private firms. To the extent that private firms can turn to public resources when they are faced with costs, our ability to influence their behaviour approximates that of government. Second, it may be that liability rules have a greater impact on public firms, if those firms react to potential political costs to which private firms may be less sensitive.

226 That is, even if we could identify this intra-bureau node, we should impose liability only when we assume that the bureau did not take into account the social costs ex ante. As I argued earlier, that assumption cannot be true in all cases, and in any event the alternative political accountability mechanisms will force internalization to some degree. 
administrative costs associated with lost internalization are minimal will liability rules be an effective technique to internalize losses.

The current budgetary allocation process does not force departments to internalize tort costs, and I doubt whether it is possible to design an efficient budgetary process that would achieve this outcome. Even if it were, the accountability mechanism consisting of budgetary and fiscal review would not need to be triggered by the economic signal of tort claims. The description of the current budgetary mechanisms within government confirms the proposition that the economic environment of the state will effectively insulate it from liability rules unless it chooses to be bound by them. It may be that in limited circumstances it ought to do so, but incentives imposed by exogenous institutions do not appear to be a necessary or viable regulatory technique. At best, tort claims might be a useful signal of breakdowns in other accountability mechanisms, but one must question whether other, more effective, signalling devices might be designed instead.

\section{Conclusion}

One purpose of tort law is to reduce the cost of accidents. In this paper I have explored the possible implications of using tort law to minimize the number and severity of accidents associated with activities of the federal government. The problem one faces in designing a regulatory instrument intended to influence government activity is to create an institution that permits interests of the constituency of 'potential and actual victims of state action' to be reflected (internalized) in public policy analysis and decision-making. My analysis suggests that tort law does not seem to be the instrument one would choose to achieve that end. Yet one advantage of tort law is that the victims of state action have a direct economic incentive to signal the harm which the government's activities have imposed or will impose on them. If we eliminate economic compensation from the regulatory instrument we must incorporate alternative incentives for victims to inform the relevant alternative regulatory actors of their losses. Potential victims can be expected to signal government if they perceive that the expected gains from signalling their potential losses (the gains associated with modification of the relevant program) exceed the costs of signalling. Actual victims will signal to the extent that we provide private incentives for them to do so. Again, the private incentive does not have to be related to their losses. Rather, we should set the amount of 'recovery' so that the expected gain on signalling just exceeds the signalling costs.

Since tort law is inappropriate as a vehicle to achieve that end, we 
should consider alternative institutions that might be more successful. One candidate is a review institution that is independent of the government unit subject to the complaint, and that has the information, political power, and budgetary and managerial authority to respond to the economic signal which the liability rule represents. ${ }^{227}$ Assuming that the review institution within the government is motivated by social welfaremaximizing objects, this institution could act as a focus for individual complainants to disclose their losses. The institution could then function simply as a conduit for the information about the losses associated with state action, which is all that is necessary if our assumption about motives is correct. This regulatory instrument could include the use of publicity by the review institution, which would permit alternative systems of political accountability to operate more effectively. ${ }^{228}$

The conclusion we can draw from this analysis is that tort law, as it is presently conceived, is a poorly designed instrument to achieve regulatory objectives in the case of state action. Tort law operates as an effective behaviour-modification technique only in so far as it uses economic costs to signal the government that its activities are associated with private losses. To influence state action we must couple the signal with budgetary and legislative constraints. These constraints are expensive and are prone to their own error costs. More important, to the extent that the constraints are operating effectively the need for economic signals is questionable. We might better direct our efforts towards designing effective 'political' markets instead of attempting to use economic signals to influence state and bureaucratic action.

227 The institution could be associated with an information-gathering function.

228 See Fox 'Corporate Sanctions: Scope for a New Selectivism' (1982) Mersey $L R$ 26, and B. Fiss and J. Braithwaite The Impact of Publicity on Corporate Offenders (Albany: State University of New York Press 1983) 